\title{
Scandal Potential: How Political Context and News Congestion Affect the President's Vulnerability to Media Scandal
}

\author{
BRENDAN NYHAN*
}

\begin{abstract}
Despite its importance in contemporary American politics, presidential scandal is poorly understood within political science. Scholars typically interpret scandals as resulting from the disclosure of official misbehavior, but the likelihood and intensity of media scandals is also influenced by the political and news context. This article provides a theoretical argument for two independent factors that should increase the president's vulnerability to scandal: low approval among opposition party identifiers and a lack of congestion in the news agenda. Using new data and statistical approaches, I find strong support for both claims. These results suggest that contextual factors shape the occurrence of political events and how such events are interpreted.
\end{abstract}

From Iran-Contra to Monica Lewinsky, presidential scandal has come to play an especially important role in contemporary American politics since Watergate, but it remains an elusive and poorly understood topic within political science. ${ }^{1}$ To date, most quantitative research on scandal has focused on the effects of allegations of impropriety on trust in government and the media, ${ }^{2}$ members of Congress ${ }^{3}$ or the president. ${ }^{4}$ No clear understanding has emerged about the context in which scandals involving legislators are most likely to occur, however - Peters, Welch and Hibbing find no obvious time trend, partisan differences or effect of length of incumbency on scandals involving members of the House of Representatives ${ }^{5}$ - and no one has systematically analyzed why presidential scandals occur. ${ }^{6}$ In particular, even though scandals forced out (or seriously threatened) the tenures of three of the last eight presidents (Nixon, Reagan and Clinton), we know little about why scandals happen to presidents at some times and not others.

* Department of Government, Dartmouth College (email: nyhan@ dartmouth.edu). I thank John Aldrich, Michael Brady, Brian Fogarty, Seth Freedman, James Hamilton, Karen Hoffman, Daniel Lee, Walter Mebane, Jacob Montgomery, Michael Munger, David Rohde, Charles Shipan, Keith Smith, Georg Vanberg and anonymous reviewers for helpful comments. I am also grateful to Marshall Breeding of the Vanderbilt News Archive, Andrew Forcehimes and Brian Newman for sharing data and to Stacy Kim and Gracelin Baskaran for research assistance. Finally, I thank the Robert Wood Johnson Foundation for generous support. A supplementary online appendix and replication dataset and code are available at http://dx.doi.org/doi:10.1017/S0007123413000458.

1 Cameron 2002, 655.

2 See, for example, Bowler and Karp 2004; Zimmer 1979.

3 See, for example, Peters and Welch 1980; Welch and Hibbing 1997.

4 See, for example, Fackler and Lin 1995; Meinke and Anderson 2001; Ostrom and Simon 1985.

5 Peters and Welch 1980; Welch and Hibbing 1997.

${ }^{6}$ Previous studies have examined the relationship between divided government and Congressional investigations of the executive branch, but such investigations are an endogenous part of the process by which scandals are created rather than the outcome of interest (see Kriner and Schwartz 2008; Mayhew 2005; Parker and Dull 2009; Parker and Dull 2013). 
One problem is how scandal has been conceptualized. Scholars have typically defined scandal as the result of the disclosure of some act of wrongdoing or norm violation. ${ }^{7}$ However, whether any specific case meets such a standard is often unclear or contested. Moreover, such a normative standard is less useful in understanding when scandals are perceived to occur in public debate, particularly when there is no definitive evidence of misconduct. In such cases, context appears to influence whether a scandal is believed to have occurred. When the political and news environment is unfavorable, scandals may erupt in the press despite thin evidentiary support. By contrast, under more favorable conditions, even well-supported allegations can languish.

I thus develop a new theory that focuses on media scandal - the widespread recognition of a controversy as a scandal in mainstream press coverage. ${ }^{8}$ According to my theory, these media scandals reflect a widespread elite perception of official wrongdoing, corruption or misbehavior that is jointly created by the opposition party and the press in the contemporary era. While the occurrence of scandal will, of course, be affected by the strength of the available evidence of misconduct, the potential for media scandal in a given time period should also vary considerably depending on the political and news context, which shapes the behavior of the press and the opposition party.

In this article, I identify two independent factors that should be especially important in creating the potential for media scandal. First, as opposition party identifiers view the president more negatively, the demand for scandal coverage and allegations should grow, which should induce additional scandal coverage and allegations that will thereby increase the likelihood of scandal. Conversely, when opposition identifiers have more positive attitudes about the president, the incidence of media scandal should decrease. Secondly, competition from other news stories can reduce the incentive to pursue allegations of wrongdoing or crowd them off of the front page relative to 'slow news' periods in which the opportunity costs of pursuing scandal coverage are lower. As a result, media scandals will be more likely to emerge when the news agenda is less congested.

I test these hypotheses using data for the 1977-2008 period from the Washington Post, which is the leading outlet for coverage of national political scandal in the mainstream US media. I find that low approval of the president among opposition party identifiers significantly increases the likelihood of media scandal onset. I also use the incidence of exogenous disasters and tragedies as an instrumental variable to show that pressure from competing news stories has a substantial negative effect on the likelihood and intensity of scandal coverage. Taken together, these findings demonstrate the role played by political context and news congestion in determining when an administration will experience a media scandal.

\section{A NEW APPROACH: DEFINING A MEDIA SCANDAL}

One explanation for the lack of quantitative research on scandal is that the concept itself not been adequately conceptualized. To date, most scholars have defined it as the public disclosure of an ethical or moral transgression - for example, "the publicization of a

${ }^{7}$ See, for example, Apostolidis and Williams 2004, 3-4.

${ }^{8} \mathrm{My}$ use of the term 'media scandal' should be read as referring to mainstream news sources. The partisan media may help to create scandals, but it is mainstream media coverage that both defines which events are recognized as scandals and brings them to a wider audience. 
transgression of a social norm'. 9 Some scholars define political scandal more specifically as a violation of the norms governing elected officeholders - for example, 'activity that seeks to increase political power at the expense of process and procedure'. ${ }^{10}$ However, these evidence-based definitions are not only difficult to measure or quantify but also fail to accurately classify the outcomes we observe in contemporary politics. ${ }^{11}$ In particular, the normative standards that are typically used to define scandal change over time and are applied inconsistently - some well-documented transgressions fail to generate much controversy in the media, while other allegations are covered as scandals despite little evidence that norms were violated. ${ }^{12}$ In such cases, the political and news context, rather than evidence, often appears to be the decisive factor.

Others are skeptical about whether scandals necessarily entail norm violations and focus instead on the response to alleged transgressions. ${ }^{13}$ For instance, Thompson writes that " "[s]candal" refers to actions or events involving certain kinds of transgressions which become known to others and are sufficiently serious to elicit a public response'. ${ }^{14}$ While dispensing with a strictly evidence-based definition is useful, these authors tend to rely heavily on public responses to alleged wrongdoing to define scandal, an approach that conflates the existence of elite controversy with the level of public outrage that ultimately results. In reality, while the most salient scandals generate high levels of public awareness and attention, most are not widely known and generate relatively little public interest (for example, Whitewater).

My theoretical approach helps reconcile the two perspectives described above. I do not rely on evidence alone to define scandals, nor do I assume that scandals can be defined solely by public outrage. Instead, I rely on news coverage, which is essential to contemporary scandal - Waisbord calls it 'the barometer that indicates the existence (or absence) of a scandal'. ${ }^{15}$ Given the way that reporters tend to index elite opinion, ${ }^{16}$ I argue that media recognition of a controversy they are covering as a scandal is the best contemporaneous indicator of whether a political figure or government official is widely believed by elites to have acted in a manner that contravenes established moral, political or procedural norms. I define controversies that have been recognized in this way as media scandals.

Though these contextual factors will affect whether a media scandal develops, it is important to be clear that factual evidence of wrongdoing, corruption or misbehavior will also be associated with the occurrence of media scandals. In particular, the evidence supporting an allegation will sometimes be so compelling that a media scandal will ensue regardless of the context. At the other extreme, certain allegations are so trivial or implausible that they will never be covered as scandals. Most of the time, however, the evidence supporting an actual or potential scandal allegation is relatively ambiguous and can be interpreted in different ways. In such cases, the political and news context will play an important role in whether (or how) the allegation is promoted by the opposition party and covered by the press for the reasons explained below.

9 Apostolidis and Williams 2004, 3-4.

10 Markovits and Silverstein 1988, 6-7.

11 Bennett 2004, 292.

12 Adut 2005; Entman 2012.

13 Adut 2005, 216.

14 Thompson 2000, 13.

15 Waisbord 2004, 1079.

16 Bennett 1990; Zaller and Chiu 1996. 
THE ROLE OF CONTEXT IN MEDIA SCANDAL

In this section, I present a theory in which media scandals are a 'co-production' of the press and the opposition party. According to this view, the recognition of scandal in the press is not strictly a reflection of ethical transgressions by public figures but a socially constructed event in which the actions (or alleged actions) of a public figure or institution are successfully construed as violating ethical norms. ${ }^{17}$ As such, while evidence plays an important role in whether any given allegation will become a scandal, the likelihood that an allegation of wrongdoing, corruption or misbehavior will be portrayed as a scandal in press coverage during a given time period should vary depending on the political and news context. In some cases, it will only take a spark from a relatively flimsy allegation to set off a significant controversy, while other environments will be much less prone to scandalous conflagrations. I first introduce my theoretical conception of this process before describing two independent factors that I expect will affect the likelihood that a scandal will take place.

\section{Media Scandal as a Co-production}

In contemporary American politics, the opposition party and the elite political media (the national print and television outlets that often set the agenda for the rest of the press) are the two crucial institutional players in creating and sustaining presidential and executive branch scandals. ${ }^{18}$ Each group has professional incentives to investigate and publicize alleged misconduct by the president and his administration. When both groups promote an allegation, a scandal will often emerge. ${ }^{19}$

First, the opposition party has strong incentives to try to create scandal in order to discredit the president or damage his political standing - what Ginsberg and Shefter call 'politics by other means'. ${ }^{20}$ In addition, scandals can have potentially damaging second-order effects on a party's brand name, a collective good that the president shares with his fellow co-partisans. ${ }^{21}$ This externality creates an important additional incentive for the opposition to try to foment scandal.

Similarly, the press has became far more willing to engage in aggressive coverage of scandal in recent years, a change that is frequently attributed to the Vietnam War and/or

${ }^{17}$ This theoretical approach helps bridge the gap between two competing perspectives on the occurrence of social and political events such as scandal. For many years, scholars took it as a given that news reporting objectively identified social problems that were worthy of coverage. In this view, news accounts of scandal would be interpreted as resulting from wrongdoing by a public figure. However, critics argued that these processes are inherently socially constructed (Molotch and Lester 1974; Woolgar and Pawluch 1985), with some denying that objective conditions have any effect (Best 1993). A more defensible approach that avoids these two extremes is the 'weak or contextual version' of social constructionism proposed by Fine, who interprets the Fatty Arbuckle scandal of 1921-22 as the partial result of public concern about moral standards in Hollywood (Fine 1997). Likewise, I view political and news context as playing an important (but not determinative) role in transforming political events into scandals.

${ }^{18}$ While this article focuses on presidential scandal in the United States, it has potential applications to state governors as well as presidential and parliamentary governments outside the United States. See the conclusion for further discussion.

${ }^{19}$ Individual media outlets or legislators may of course behave idiosyncratically, but both are part of institutions - a formal institution in the case of parties and an informal one in the case of the press (Cook 2005 ) - that generate relatively consistent patterns of behavior. For parties, see, for example, Groeling 2010; Grynaviski 2010. For the press, see, for example, Bennett 2004, 292; Crouse 1973; and Sabato 1991, 59-61.

${ }^{20}$ Ginsberg and Shefter 2002.

${ }^{21}$ Adut 2005; Groeling 2010; Grynaviski 2010; Snyder and Ting 2002. 
Watergate. ${ }^{22}$ Breaking news about a major scandal now creates prestige for journalists and can lead to increased consumer interest. ${ }^{23}$ As a result, journalists often compete to report about possible misconduct first. After these stories are published, the pressures of pack journalism often generate waves of similar stories. ${ }^{24}$

When both the press and the opposition party draw attention to an allegation against the president or his administration, the result can be an accelerating sequence of news reports and opposition party criticism that generates a media scandal. For such a process to occur, the participation of both groups is essential. Indeed, the interactions that take place among the opposition and members of the press as a scandal develops are consistent with the 'negotiation of newsworthiness' described by Cook. ${ }^{25}$ The opposition helps the press 'make news' by providing information to reporters and staging news events, while the press helps the opposition by providing exposure for potentially damaging allegations against the president. ${ }^{26}$

Conversely, it is difficult for either the opposition or the press to pursue scandal allegations against the president without the participation of the other group. Most notably, the press tends to avoid pursuing critical stories without cover from the opposition due to its tendency to track conflict among elites. ${ }^{27}$ Quoting opposition party members thus helps to legitimize reporting on scandal allegations and protect reporters' reputation for objectivity. ${ }^{28}$ In contrast, when the opposition does not pursue an allegation, reporters may be reluctant to cover the story due to a lack of sources and the risk of appearing biased. For instance, Entman notes that potential scandals concerning the Bush administration's connections to Enron and the Florida recount 'died in the absence of sustained opposition campaigning or effective uses of political processes'. ${ }^{29}$ In addition, it is extremely difficult for the opposition to create a widespread perception of wrongdoing without media coverage.

The exact process by which media scandals originate will necessarily vary. Allegations may be initiated by the media or opposition elites, but they can also originate with interest groups, government watchdogs or administration whistleblowers. In some cases, the process will be driven by law enforcement or investigative processes such as Congressional committees and special counsels, while others may be fought primarily through the media. In each case, though, the joint participation of the press and opposition is critical to the creation of a media scandal.

What role does the president play in this process? Most notably, the likelihood of media scandal of course depends in part on the availability of potential scandals for the press and opposition party to publicize. Potential targets almost always exist, given the relatively weak role that evidence plays in scandal and the president's responsibility for the entire executive branch. However, the supply of potential scandals is surely affected

22 See, for example, Farnsworth and Lichter 2006; Sabato 1991; Thompson 2000.

23 Thompson 2000, 78; see, for example, Hamilton 2004, 288-9.

24 Bennett 2004, 292; Crouse 1973; Sabato 1991, 59-61.

25 Cook 2005.

26 See also the 'cascading network activation' model of scandal in Entman 2012.

27 Bennett 1990; Stimson 2004, 146-47; Zaller and Chiu 1996.

28 Tuchman 1972, 668.

29 Entman 2004, 292-3. Similarly, local coverage of members of Congress implicated in the Abramoff scandal was found to be concentrated in competitive races and largely consisted of stories citing their challengers, which insulated reporters from criticism. In the absence of a competitive challenger raising the issue, however, the scandal received little attention (see Fogarty 2013). 
by the actions of the president and his administration, and is likely to change over the course of their time in office. For instance, a new president is vulnerable to scandals in the backgrounds of his executive branch nominees but has made few other decisions that could be criticized. Over time, however, his record will grow longer, increasing the set of possible targets. In addition, the likelihood of scandal may vary across administrations due to differences in ethics, reputation or political skill. Finally, the White House may try to prevent scandals or limit their magnitude, but the extent of damage control and its likelihood of success will largely depend on the available evidence (discussed above) and the political and news context (see below).

The role of context in scandal. When are media scandals most likely to occur? The process is, of course, stochastic - for instance, the supply of allegations that can be publicized without generating libel or slander lawsuits will vary idiosyncratically. ${ }^{30}$ However, contextual factors will have systematic effects on the incentives of the media and the opposition - whom I expect to weigh the costs of investigating and publicizing scandal allegations against the likelihood of successfully creating a scandal ${ }^{31}$ - and will thereby affect the likelihood that they will jointly help to create a media scandal. Specifically, I focus on two contextual factors that should independently affect the likelihood of media scandal - approval of the president among opposition party identifiers and the level of congestion in the news agenda. In each case, our interest is in the effect of the contextual factor in question on the likelihood and intensity of scandal, which should be null if evidence is the only factor of significance.

Opposition approval. A number of recent studies has found that contemporary legislators are highly responsive to partisan, activist and primary constituencies. ${ }^{32}$ Given the partisan nature of scandal in the post-Watergate era, I expect parties to be especially responsive to demand for scandal from their supporters, which should vary depending on opposition identifiers' feelings toward the president. When opposition identifiers are hostile to the president, for instance, the literatures on motivated reasoning ${ }^{33}$ and public opinion about scandal ${ }^{34}$ suggest that they should be more interested in and supportive of scandal allegations against the president and less sensitive to the evidentiary basis for these claims. Under these circumstances, I expect that opposition elites will be more likely to pursue scandal allegations to meet the demand for negative information about the president from their base. By contrast, during periods when opposition identifiers are more supportive of the president such as 'honeymoons', foreign policy crises and the initial stages of wars $^{35}$ - they should be less interested in and inclined to believe allegations against the president. As a result, the opposition party should reduce the flow of negative messages, ${ }^{36}$ including scandal allegations or investigations and statements that could lead to scandals. (Consider, for instance, the

\footnotetext{
${ }^{30}$ Again, I do not focus on allegations of wrongdoing as a theoretical or empirical factor. For the purposes of this study, they are an endogenous mechanism in the scandal-generating process, not a causal effect of interest. Other factors that may affect the supply of potential scandals are discussed further below.

${ }^{31}$ Fogarty 2008, 449; Szasz 1986.

32 See, for example, Brady, Han, and Pope 2007; Clinton 2006; Layman et al. 2010.

33 See, for example, Kunda 1990; Redlawsk 2002; Taber and Lodge 2006.

${ }^{34}$ See, for example, Blais et al. 2010; Fischle 2000.

${ }^{35}$ Lebo and Cassino 2007; Newman and Forcehimes 2010.

${ }^{36}$ Brody 1991.
} 
change in how Democrats treated George W. Bush after the 9/11 terrorist attacks.) This reduction in negative information flow about the president should lead to a corresponding shift toward more positive mainstream news coverage due to the media's tendency to reflect levels of elite conflict. ${ }^{37}$ As such, we would expect fewer stories about scandals, scandal allegations or potential scandals when opposition identifier approval is relatively high.

Support for the president among opposition party identifiers is also likely to directly affect scandal coverage by the press, which has been found to be responsive to audience demand despite prevailing norms within journalism. ${ }^{38}$ Opposition identifiers are the most receptive audience for presidential scandal news, and are thus likely to influence how scandal allegations are covered. However, the literatures on motivated reasoning and public responses to scandal discussed above suggest that opposition identifiers' demand for scandal news should vary depending on their feelings toward the president. When the other party's base is more supportive of the president (as in the case of honeymoons $\mathrm{s}^{39}$ and foreign policy crises), demand for negative news about the president from the media - including scandals - should decrease. ${ }^{40}$ Conversely, as approval decreases among opposition identifiers, demand for scandal reporting and other negative coverage should increase. ${ }^{41}$

Finally, as noted earlier, the press and the opposition party have a symbiotic relationship; neither can generate a scandal alone. Because both groups face similar incentives, I hypothesize that the likelihood of jointly generating the positive feedback dynamics that create a scandal will vary depending on the president's standing with the opposition party:

Hypothesis 1: As support for the president increases among opposition party identifiers, the likelihood of scandal should decrease.

However, I make no predictions about the effect of support for the president among opposition identifiers on the magnitude or intensity of scandal. The most significant scandals have tended to occur during presidents' second terms in office. ${ }^{42}$ Because presidents who have higher approval ratings are more likely to be re-elected, ${ }^{43}$ the relationship between opposition approval and scandal magnitude or intensity is confounded.

37 Bennett 1990; Stimson 2004, 146-7.

38 See, for example, Gentzkow and Shapiro 2010; Hamilton 2004; Puglisi and Snyder 2011. While journalists may not always closely peruse the cross-tabs of job approval surveys, the opposition party's feelings about the president are typically clear to political observers. For instance, Bill Clinton averaged 23 per cent approval in Gallup polls among Republicans during his first year in office (Jones 2010) - by far the lowest of any modern president to that point. It was widely understood at the time that Clinton was dogged by low opposition support in a polarized political environment (see, for example, Cannon 1993).

39 There is some evidence that the magnitude of the honeymoon effect in presidential approval and favorable news coverage has declined in the contemporary period (for example, Farnsworth and Lichter 2004; Jacobson 2003).

40 Brody 1991.

41 Corroborating evidence is available from Clayman et al. (2007), who find that reporters are more adversarial toward the president when unemployment and interest rates are higher. (They find that presidential approval does not significantly improve the fit of their model, but that is likely an artifact of the correlation between approval and the economic variables they include as predictors.) Entman (1989) also states that news slant is more negative when the president is less popular, though conflicting findings have been reported on the relationship between approval and negativity in presidential news coverage (Cohen 2008, 2009).

42 Shogan 2006.

43 See, for example, Abramowitz 2008. 
Congestion of the news agenda. A second contextual factor that may affect the occurrence of media scandal is congestion in the news agenda. While the 'slow news' claim may be familiar, its implications for understanding the nature and causes of media scandal are less well understood. In particular, the slow news hypothesis suggests that the likelihood of a presidential media scandal during a given time period is not just a function of the available evidence of wrongdoing but also of the news context during that period.

To understand the effects of news context on scandal coverage, it is necessary to consider how media outlets allocate resources. Each outlet has a limited number of journalists and a finite amount of space in which to present stories. The attention devoted to a particular story thus depends on the context in which it occurs. ${ }^{44}$ In particular, when few major stories are available, the opportunity costs of scandal coverage are low. As such, media outlets are more likely to investigate and report on potential scandals involving the president or his administration and to give more prominent placement to those stories that they do report. Qualitative research and journalistic reports have frequently attributed scandals to slow news periods for this reason. ${ }^{45}$ For instance, Howard Kurtz of the Washington Post suggested that a 1991 controversy involving White House chief of staff John Sununu was exacerbated by it taking place during a 'slow news period' ${ }^{46}$

By contrast, when the news agenda is congested, the opportunity costs of covering a given story will increase. Eisensee and Strömberg demonstrate this effect in a study showing that external events frequently crowd out media coverage of foreign disasters. ${ }^{47}$ Political scandals, which generate relatively low levels of public interest compared with other types of news stories, ${ }^{48}$ are similarly vulnerable to news congestion. Busy news periods will thus reduce the likelihood that mainstream news outlets will pursue scandal coverage or give it prominent placement. For example, the drumbeat of post-9/11 news helped to protect 'scandal-plagued' Army Secretary Thomas White for much of $2002 .{ }^{49}$ Similarly, the build-up to the Iraq War may have helped crowd out the 'potential scandal' of the Bush administration's ties to the corporate scandals of 2001-02. ${ }^{50}$

Congestion of the news agenda will also affect the behavior of the opposition party and the press. When another story is dominating the news, both groups will be less likely to promote allegations of wrongdoing for fear of being drowned out by other news stories, reducing the supply of potential scandal coverage. By contrast, opportunistic reporters and politicians are more likely to promote a possible scandal during a slow news period when there are few competing stories. As such, I hypothesize that slow news periods can foment scandals, while high levels of news pressure can crowd out potential scandals:

Hypothesis 2: As the news agenda becomes more congested, the likelihood and intensity of scandal should decrease. Correspondingly, when fewer competing news stories are available, the likelihood and intensity of scandal should increase.

44 Entman 1989, 52

45 See, for example, Allen 1982; Cook 1991; Green 2002; Kurtz 1991; Sabato 1991; Smith and Smith 1994.

46 Kurtz 1991.

47 Eisensee and Strömberg 2007.

48 Robinson 2007.

49 Green 2002.

50 Farnsworth and Lichter 2006, 132. 
It is important to note that my theory does not specifically predict that the effect of news pressure is moderated by opposition approval (or vice versa). I expect both factors to have independent effects on media scandal. I therefore do not offer such a hypothesis or test interaction terms below.

\section{DATA AND METHODS}

This section introduces the variables used in the statistical analysis and explains how they are derived from the theory presented above. It also introduces the duration modeling and instrumental variables approaches used in the statistical analysis, which examines the relationship between the political and news context (the independent variables of interest) and the onset and intensity of media scandal (the outcome variables of interest) in a given time period (week). ${ }^{51}$

\section{Dependent Variables: Scandal Onset and Intensity}

I construct two types of dependent variables for the entire 1977-2008 period: scandal onset, which measures whether a media scandal starts in a given week, and scandal intensity, which measures the volume of coverage of a media scandal in a given week. In each case, I do not disaggregate the dependent variable by type of scandal (for example, sexual, financial, etc.); target (White House or elsewhere in the executive branch); or characteristics of the allegation (for example, public or private behavior, whether the actions took place before the official took office, etc.). Though these distinctions can be important, ${ }^{52}$ disaggregating the data further would simply leave us with too few media scandals of each type to analyze statistically. More importantly, while various sorts of heterogeneity are possible, the political and news context is likely to play a similar role across all of these cases. For instance, even when the president is not directly responsible for a given controversy (for example, a dispute over actions taken within the executive branch), he is held politically responsible for scandals and expected to address any problems that have been revealed. Moreover, his vulnerability to scandal of all types will increase as the political and news context become less favorable (as described below).

The first dependent variable is media scandal onset - a binary measure of whether a major new media scandal was recognized as such by the press in a given week. Analyzing the predictors of this dependent variable will help us determine the conditions under which a media scandal is likely to emerge. In this sense, my measure of media scandal onset is no different than analyses of other binary event indicators of latent continuous processes, such as interstate and civil wars or regime transitions. It would, of course, be desirable to analyze the full sequence of events that takes place during each scandal (including the actions of third-party groups, the making of scandal allegations, Congressional and independent counsel investigations, etc.), but that process is highly complex and frequently unobservable. In addition, many of the mechanisms of scandal,

\footnotetext{
${ }^{51}$ It is impossible to measure (or even conceptualize) the universe of possible scandals, which would need to include not just all the allegations that do not become media scandals, but the possible allegations that are not made and the transgressions that are not observed. (The observed set of allegations or transgressions is likely to be affected by the independent variables of interest. Conditioning on them could therefore induce post-treatment bias.) As such, there is no way to estimate a model predicting which allegations or transgressions become scandals, nor is it possible to directly estimate the effects of political and news context - which vary over time - in such a framework.

52 See, for example, Basinger 2013; Doherty, Dowling and Miller 2011; Funk 1996.
} 
including the presidential response strategies discussed by Basinger and Rottinghaus, are intermediate outcomes whose occurrence is likely to be endogenous. ${ }^{53}$ Similarly, too few scandals exist under any reasonable definition to estimate an adequate statistical model of their duration. I therefore analyze a measure of scandal intensity below.

The measures of scandal used in this study are constructed from data on mainstream media coverage of scandal. In particular, my primary measure of scandal onset tracks when news reporters first describe a controversy involving the president or executive branch as a 'scandal'. Because journalists tend to index elite opinion ${ }^{54}$ - particularly on sensitive issues like allegations of governmental wrongdoing - the use of the term 'scandal' in news reporting is a useful contemporaneous measure of elite perceptions. If reporters index elite opinion in their use of the term 'scandal', then the transition to using the term is a theoretically meaningful event. While some may object to my focus on journalistic terminology, reporters are highly systematic in their use of pejorative terms and tend to follow elites in their use of those terms. For instance, Bennett, Lawrence and Livingston argue that the media avoided using the term 'torture' in coverage of prisoner treatment at Abu Ghraib due to the lack of a 'consistent and organized political opposition'. 55

In this case, the pattern of usage of the term 'scandal' is consistent with the indexing hypothesis, which suggests that its use is an important reflection of real-world dynamics in Washington. Some controversies that were widely viewed as scandals were almost immediately described as such (for example, Abu Ghraib), while other controversies that were not broadly seen as scandals were described in other terms (for example, pre-war Bush administration claims about Iraqi weapons of mass destruction). To take one example, the Washington Post studiously avoided using the term 'scandal' to describe Whitewater in almost 200 news reports between 31 October 1993 and 8 June 1994 language that reflected the state of the controversy at the time. However, as the allegations became more prominent, the Post began using the word 'scandal', which captured the new political reality.

To measure this construct, I follow Meinke and Anderson in using the Washington Post as a proxy for scandal coverage in the national mainstream media. ${ }^{56}$ The Post is an influential outlet that often sets the agenda for national politics coverage (including scandals) for reporters nationwide. ${ }^{57}$ For instance, a 2003 New York Times report on the controversy over the disclosure of Valerie Plame's identity stated, 'The Washington Post published a prominent article on the front page, one mark of a burgeoning scandal here. ${ }^{58}$

53 Basinger and Rottinghaus 2012. George W. Bush, for instance, took a far different approach to damage control in the immediate post-9/11 period (when he enjoyed high news congestion and high opposition approval ratings) than at the end of his time in office.

54 Bennett 1990; Zaller and Chiu 1996.

55 Bennett, Lawrence, and Livingston 2006.

56 Meinke and Anderson 2001.

57 Many observers believe that the national media has become more divided along ideological lines, but this trend is relatively recent. Fox News Channel, for instance, only reached a median primetime viewership of one million viewers in 2002 (Holcomb, Mitchell, and Rosenstiel 2011). For the vast majority of the 1977-2008 period covered by my data, mainstream news coverage was much more frequently characterized by - and criticized for - 'pack journalism', especially in its coverage of presidential scandal (Bennett 2004, 292; Crouse 1973; Sabato 1991, 59-61). These similar patterns of coverage reflect institutional norms that are shared within the press (Cook 2005).

58 Rosenbaum 2003. 
Using Post articles published between 1977 and $2008,{ }^{59}$ I determine the first time the Post published a front-page story focusing on a controversy concerning the president and executive branch that described it as a scandal in the reporter's voice or headline, a precise and replicable approach designed to minimize false positives and subjectivity. ${ }^{60}$ This restriction helps identify the most salient controversies at the point at which they are prominently recognized as media scandals, ${ }^{61}$ the outcome of interest. In particular, as former CBS anchor Dan Rather noted, front-page coverage in the Post and other prominent newspapers tends to drive television coverage: 'If the Washington Post, the New York Times, or the Los Angeles Times runs a front-page story...the heat's on to run it and we usually do'. ${ }^{62}$ The twenty-eight media scandals identified using this approach, which are listed in Appendix A, correspond closely to other accounts and popular perceptions, which suggests that the reporters' use of the term is a meaningful indication of perceived presidential or executive branch wrongdoing.

When scandals occur, what determines whether they set off a wild feeding frenzy ${ }^{63}$ or quickly fizzle? Because there are too few media scandals that fit the definition presented above to estimate a statistical model of their duration, I instead use the Post data to create a longitudinal measure of the volume of scandal coverage, which serves as a proxy for the overall magnitude or intensity of scandal in a given time period. I measure this concept by summing the number of front-page articles that describe a controversy involving the president or executive branch as a scandal by week. The resulting time series, which is plotted in Online Appendix A, closely corresponds to qualitative observations of presidential scandal magnitude in the post-Watergate era.

\section{Independent Variables}

Opposition approval. I operationalize Hypothesis 1 using approval of the president among opposition party identifiers. To measure this variable, I employ data from Lebo and Cassino and Fox measuring the proportion of Republican and Democratic identifiers (not including leaners) that approves of the president in Gallup or CBS/New York Times data. ${ }^{64}$ Data for this variable, which are available at the monthly level, were lagged by one month to guard against endogeneity. ${ }^{65}$

59 These articles were collected from the Nexis news database, which only includes Post articles published since 1 January 1977. After these data were collected, ProQuest Historical Newspapers made Post content available for the 1877-1995 period, but the coding procedure described in Appendix A cannot be replicated in their database.

${ }^{60}$ Inter-coder reliability for scandal coding was very good (95 per cent agreement among three coders, Krippendorff's Alpha $=0.78)$. The procedure used for coding article focus also showed high reliability $(92$ per cent agreement among two coders, Krippendorff's Alpha $=0.84$ ). Appendix A provides further details.

${ }^{61}$ Sabato 1991, 134.

${ }^{62}$ Sabato 1991, 134.

${ }^{63}$ Sabato 1991.

${ }^{64}$ Fox 2009; Lebo and Cassino 2007.

${ }^{65}$ When a week included days from two months, the approval rating for the month in which the median day from that week took place (that is, Wednesday) was used. To avoid dropping data, each new president's first recorded value for opposition approval is treated as the lagged value for his initial time in office when lagged values are missing. Values were linearly interpolated for later months in which approval data were missing (Lebo and Cassino 2007, 727). A plot of lagged approval ratings for opposition party identifiers (as well as independents and identifiers of the president's party) is provided in Online Appendix B. 
News pressure. The other primary independent variable of interest is congestion in the news agenda, which I use to test Hypothesis 2. This variable, which is derived from Eisensee and Strömberg, measures the average length of the first three segments of the network newscasts (in minutes) at the weekly level for $1977-2008{ }^{66}$ Unlike newspaper front pages (which feature a largely static number of stories), this measure varies widely in response to events - when important news breaks, the networks devote much of their broadcast to that story. By contrast, they present a larger number of short segments during slow news periods. The resulting variable appears to have high face validity, showing spikes during events such as the 11 September attacks and the 2003 invasion of Iraq. Given the prevalence of pack journalism among elite news sources, ${ }^{67}$ it is very likely that this news pressure indicator is a valid measure of the presence or absence of significant competing stories for all forms of elite mainstream outlets, including the Post and other newspapers. (A graph of the measure and further details about how it was constructed are provided in Online Appendix C.)

Control variables. In addition to opposition approval and news pressure, I also control for other variables that may affect the incidence and magnitude of scandal but are not central to the theoretical or empirical focus of this study.

First, I include an indicator for divided government. Opposition party control of one or both chambers of Congress may increase the likelihood of scandal because the opposition can use Congressional committees to investigate the executive branch, ${ }^{68}$ though empirical evidence on this point is mixed. ${ }^{69}$ Divided government also appears to have played a key role in keeping the independent counsel statute in force, which could also lead to more scandals. ${ }^{70}$ Finally, the press is likely to provide greater coverage of opposition party criticism of the president under divided government, ${ }^{71}$ which could result in greater coverage of scandal allegations and thus more scandal.

A second possible factor is the existence of a US-led foreign war, which may divert attention from domestic politics and increase the costs of making allegations against the president. I therefore include an indicator variable that takes a value of 1 for major US wars and foreign interventions. ${ }^{72}$

In addition, several trends that are highly correlated with time may have increased the prevalence of scandal in this period, though it is not possible to separate their effects. First, growing polarization may be associated with more frequent opposition scandal allegations, ${ }^{73}$

${ }^{66}$ Eisensee and Strömberg 2007.

${ }^{67}$ Bennett 2004, 292; Crouse 1973; Sabato 1991, 59-61.

${ }^{68}$ See, for example, Ginsberg and Shefter 2002.

${ }^{69}$ Kriner and Schwartz 2008; Mayhew 2005; Parker and Dull 2009; Parker and Dull 2013.

70 Because the independent counsel was only in effect for six months under unified government after 1980 (July-December 1994), it is not possible to adequately separate the effects of the statute from divided government more generally. I thus omit an independent counsel statute indicator from the models below. As I discuss below, however, the results are not sensitive to its inclusion (details available upon request).

${ }^{71}$ Groeling 2010.

${ }^{72}$ Specifically, the war variable takes a value of 1 for the weeks that include the invasions of Grenada (23-29 October 1983) and Panama (17 December 1989-6 January 1990), the first Gulf War from the blockade to the end of hostilities (12 August 1990-2 March 1991), the war in Afghanistan from the initiation of bombing through Operation Anaconda (7 October 2001-9 March 2002), and the war in Iraq from the US invasion through the end of George W. Bush's second term (16 March 2003-31 December 2008).

${ }^{73}$ Ginsberg and Shefter 2002. 
more intensive Congressional investigation ${ }^{74}$ and larger audiences for ideological outlets such as talk radio. Similarly, the rise of cable news or other factors may have fueled an apparent trend toward greater scandal coverage in the press. ${ }^{75}$ The rise of the internet may also have helped create more scandals as audiences for websites like the Drudge Report have grown. Unfortunately, as Cohen notes, Congressional polarization and cable television audiences are so strongly confounded with time that we cannot distinguish among them $(r>0.90$ in each case). ${ }^{76}$ The number of Americans with internet access is similarly confounded with these factors $(r>0.80$ in each case). It is simply not possible to fully disentangle these variables in longitudinal data. I therefore include a simple time trend for years since 1976 that should account for all of these highly correlated factors, though my results are not sensitive to adding any of these measures as a separate variable in the robustness tests below. ${ }^{77}$

An additional possible factor is the political calendar. When Congress is in session, opposition party members may be more likely to promote scandal allegations than during recess, when they are typically attending to their constituents. The media may also be more likely to cover scandal allegations when Congress is in session if the opposition party makes floor speeches or holds committee hearings on the subject. I therefore control for the number of calendar days the House of Representatives is in session in each week. ${ }^{78}$

Finally, the population of potential scandals may vary across presidencies due to differences in the characteristics, behavior, or reputation of presidents or their administrations. I therefore include presidential fixed effects (including conditional logit, which avoids the bias and inconsistency that can result from including fixed effects in a standard logit model) in the models below to account for differences in misconduct or vulnerability to scandal between administrations. ${ }^{79}$

\section{Accounting for Duration Dependence}

In the first part of the results section below, I analyze media scandal onset by week for the 1977-2008 period. $^{80}$ This binary variable measures whether a scandal was first recognized in a given week. ${ }^{81}$ These data can therefore be analyzed as a discrete-time survival model

74 Kriner and Schwartz 2008.

75 Kalb 1998.

76 Cohen 2008, 100-101. All results available upon request.

77 The time trend could also account for concerns about declining presidential approval among opposition identifiers over time. Approval ratings of George W. Bush among Democratic identifiers did reach historic lows in his second term, but the time trend is only modestly correlated with lagged opposition approval overall $(r=-0.28)$.

78 This variable is measured as the proportion of the days of the week that the chamber was in session. I use the House because Senate data are not available electronically for 1977. Measures for the two chambers are highly correlated $(r=0.83)$, so this choice should not affect my results.

79 As discussed below, the results are also robust to the inclusion of various additional control variables including the independent counsel statute; an election year indicator; years since 1976 squared (to account for a potential non-linear time trend); the percentage of households with cable television or internet access; the number of cable news subscribers; or the distance between the party medians in Common Space DW-NOMINATE (Poole and Rosenthal 1997, 2007).

${ }^{80}$ In all of the analyses presented in this article, the incoming president is treated as being at risk of scandal starting in the first week of January during the month in which he assumes office. Presidential nominees are often targeted by scandal allegations during this late stage of the transition process.

${ }^{81}$ Each scandal can only be 'new' once. In a single case (14-20 March 1999), two closely related scandals concerning alleged Chinese nuclear espionage and improper technology transfers were recognized in the same week. 
in which the subjects (presidents) can suffer from the event of interest (scandal onset) more than once during their lifetime (time in office). Because each president in the data suffers more than one scandal, the model estimates the factors that are associated with scandals occurring more or less frequently.

In such a model, it is necessary to account for the possibility that the risk of scandal in a given time interval may be related to the length of time elapsed since the last scandal. Failing to account for such a pattern, which is known as duration dependence, can generate incorrect standard errors. ${ }^{82}$ To address this concern, I estimate what are known as conditional gap time models ${ }^{83}$ in discrete time, which account for the time since the president's last scandal. Using this approach, which assumes that the president is not at risk for his $i$ th scandal until scandal $i-1$ has already occurred, I account for the likelihood that pressure is likely to build for the opposition and press to uncover wrongdoing as the time since the last scandal increases. When a new scandal is discovered, this pressure is alleviated as 'scandal fever' gives way to 'scandal fatigue', but the pressure then again builds over time. I parameterize this risk in the models reported below using polynomials for time since the last scandal, which Carter and Signorino recommend using to account for duration dependence instead of splines due to their greater flexibility and ease of interpretation. ${ }^{84}$

However, the data also display clear temporal variation over the course of the president's tenure - most notably in the frequency of major second-term scandals. These fluctuations may correspond to possible differences in the supply of potential scandals discussed above (for example, the number of executive branch nominees). I therefore also include flexible polynomials of presidential tenure in each model to account for possible nonlinear changes in the likelihood of scandal over the course of a chief executive's time in office. ${ }^{85}$ While we lack reliable data that can be used to quantify the population of potential scandals in a given time period, these polynomials will account for any (possibly non-linear) changes in the supply of possible scandals over the course of a president's time in office as well as differences in the likelihood of successfully generating media scandals at different points in that tenure. With these terms included in my statistical models, the likelihood of scandal onset or intensity should be conditionally independent of a president's time in office and any corresponding changes in the supply of potential scandals. ${ }^{86}$

\section{Instrumental Variables Model Specification}

As noted above, we would like to estimate the effect of news pressure on the dependent variables of media scandal onset and intensity, but this relationship is almost surely

82 Beck, Katz, and Tucker 1998; Box-Steffensmeier and Jones 1997.

83 Prentice, Williams, and Peterson 1981

84 Carter and Signorino 2010. The time since last scandal term is calculated as the number of weeks divided by fifty-two (an approximation due to leap years). The cubic terms are divided by ten to ease interpretation of coefficients.

85 These are calculated in fractions of a year in the same manner as the time since last scandal variables. Both cubic terms are again divided by ten to ease interpretation.

${ }^{86}$ While it might seem desirable to directly account for evidence of wrongdoing, it is not clear how to do so. First, such evidence is not easily quantified, nor does it map cleanly into the time series data I analyze (my unit of analysis in this study is a calendar week, not an allegation). Also, as I discuss above, observed evidence (or even the existence of an allegation) is likely to be endogenous to the likelihood of scandal onset or scandal intensity. I therefore exclude covariates related to evidence or allegations from the models that follow. 
endogenous. As the volume of coverage of presidential scandal increases, overall news pressure is also likely to increase. In addition, the president may try to strategically create news to divert attention away from stories he does not want covered (the 'distraction hypothesis ${ }^{87}$ ), which could include a potential or ongoing scandal. For instance, Farnsworth notes that Bill Clinton's trip to China during the Monica Lewinsky scandal generated numerous positive news stories. ${ }^{88}$ Clinton was also accused of conducting military strikes to distract from the Lewinsky scandal. ${ }^{89}$

To address these concerns, I create an exogenous news events variable to serve as an instrument for weekly news pressure. Specifically, I create an indicator variable for the most severe mass shootings, hurricanes, celebrity deaths, earthquakes, mass suicides and plane crashes, as defined by objective criteria and third-party sources. These events should create an exogenous shock to news pressure without otherwise affecting the likelihood of presidential scandal. ${ }^{90}$ I restrict my sample to US events because these are more likely to draw public interest and thus media coverage. ${ }^{91}$ The resulting set of news events, which are listed in Appendix B along with further details on the coding procedure, includes many of the most dramatic disasters and tragedies of recent decades. ${ }^{92}$ (See Online Appendix D for more evidence supporting the assumptions of the instrumental variables model.)

In the models below, I use the exogenous news event indicator to estimate instrumental variables' regression models of scandal onset and for intensity testing of Hypothesis $2 .{ }^{93}$ By testing two outcome variables that differ in both their conceptual definitions and empirical distributions, I demonstrate that my findings are robust to variation in the assumptions employed for each specific model. The models of scandal onset $O_{t}$ and intensity $I_{t}$ in week $t$ and month $m$ that test Hypothesis 2 are specified as:

$$
O_{t}=\beta_{0}+\beta_{1} A_{m-1}+\beta_{2} N_{t}+\mathbf{X}_{t} \beta^{\sim}+\varepsilon_{t}
$$

87 Cohen 2010.

88 Farnsworth 2009, 86.

89 York 2001. Similar statistical concerns apply to efforts to account for presidential damage control efforts more generally. Controlling for the use of such strategies could induce post-treatment bias if presidents are more likely to engage in damage control in unfavorable political and news environments, which seems likely (King and Zeng 2006). Moreover, if damage control strategies are more likely to be used as the likelihood of scandal increases, controlling for their usage will also create endogeneity bias. I instead provide results from conditional logit and presidential fixed effects to account for possible differences in damage control skill between administrations.

${ }^{90}$ By contrast, events such as terrorist attacks or wars might affect the likelihood of scandal directly (by, say, inhibiting criticism of the president) and thereby violate the exclusion restriction required for my instrumental variables model to provide a valid estimate of the effect of news pressure on scandal.

91 See, for example, Robinson 2007.

92 Events occurring in the last two days of a given week were coded as taking place in the subsequent week except for hurricanes, which are often covered most intensely before landfall (which I code as the date of occurrence). While I assume that the effect of the news event on scandal is felt in the week in which it takes place, all results are robust to instrumenting for the previous week's news pressure using a lagged events variable (details available upon request).

${ }^{93}$ While discrete time survival data are typically modeled using a generalized linear model for binary data, the conditional (fixed effects) logit model used to test Hypothesis 1 below cannot incorporate instrumental variables. While IV probit models are available that omit fixed effects, these depend on strong distributional assumptions. Cameron and Trivedi $(2010,481)$ argue that OLS and IV regression models make fewer assumptions and are more robust to departures from those assumptions than their GLM counterparts (Angrist and Pischke 2009, 197-8). Finally, the exogenous news events instrumental variable perfectly predicts the outcome variable (that is, no scandal begins in the weeks in which exogenous news events occur), which causes serious estimation problems for IV probit models. 
and

$$
I_{t}=\beta_{0}+\beta_{1} A_{m-1}+\beta_{2} N_{t}+\mathbf{X}_{t} \beta^{\sim}+\varepsilon_{t},
$$

where $A_{m-1}$ represents the value of opposition approval in the previous month, $N_{t}$ represents the value of news pressure during that week and $\mathbf{X}_{t}$ is a vector of control variables, including the polynomials accounting for duration dependence described above. For expositional clarity, I separate the constant $\beta_{0}$, the coefficients for opposition approval $\beta_{1}$ and news pressure $\beta_{2}$, and the coefficient vector $\beta^{\sim}$, which represents the coefficients for the control variables in the model. Because news pressure may be endogenous, the IV models estimate the first-stage equation:

$$
N_{t}=\gamma_{0}+\gamma_{1} A_{m-1}+\gamma_{2} E_{t}+\mathbf{X}_{t} \gamma^{\sim}+\omega_{t}
$$

where $\gamma_{2}$ represents the coefficient for the exogenous events indicator $E_{t}$ and the other $\gamma$ coefficients are defined analogously to the $\beta$ terms in Equations 1 and 2. The key coefficient of interest for testing Hypothesis 2 is $\beta_{2}$, which will be consistently estimated by the IV regression models if the news events indicator is uncorrelated with $\varepsilon_{t}$ and $\omega_{t}$ and if the model meets the assumptions discussed in Online Appendix D. Both the ordinary least squares (OLS) and IV models are estimated using standard errors that are robust to arbitrary heteroscedasticity ${ }^{94}$ and autocorrelation. These models also include an indicator for peak hurricane season to ensure that the instrument is conditionally uncorrelated with the error term.

\section{RESULTS}

This section presents the results of statistical models testing the hypotheses presented above about the effects of political and news context on media scandal. If my theory is correct, then presidential approval among opposition identifiers and congestion of the news agenda should be negatively related to the onset and intensity of scandal. By contrast, if evidence is the sole cause of scandal, the effects of these contextual factors should be null.

\section{Scandal Onset}

To test my hypotheses about the relationship between political and news context and media scandal onset, I estimate two pairs of models in Table 1. The first and second columns report models testing Hypothesis 1, which predicts that the likelihood of scandal onset will decrease as the president becomes more popular with opposition party identifiers. These models exclude the news pressure variable because of the risk of inducing endogeneity bias in the estimates for opposition approval. ${ }^{95}$ (I discuss the models testing Hypothesis 2, which appear in the third and fourth columns, separately below.)

Given that the outcome is binary, my preferred estimate for Hypothesis 1 comes from a conditional logit model that predicts scandal onset in the first column, which is the logistic equivalent of a regression model with fixed effects for each president. ${ }^{96}$ Given concerns about interdependence in outcomes during a president's tenure, I employ robust standard

\footnotetext{
94 Linear probability models must be estimated with robust standard errors to account for heteroscedasticity (Cameron and Trivedi 2010, 485).

95 Including news pressure in the model testing Hypothesis 1 could also induce post-treatment bias in the estimate of the effect of opposition party approval if it affects news pressure (for instance, during wars or foreign policy crises).

96 Generalized linear models for binary dependent variables such as logit and probit are relatively interchangeable in discrete time survival models (Beck, Katz, and Tucker 1998).
} 
TABLE $1 \quad$ Models of Media Scandal Onset 1977-2008 (weekly data)

\begin{tabular}{|c|c|c|c|c|}
\hline & \multicolumn{2}{|c|}{ Hypothesis 1: Opposition Approval } & \multicolumn{2}{|c|}{ Hypothesis 2: News Pressure } \\
\hline & Cond. logit & OLS & OLS & IV reg. \\
\hline Opposition Approval (lag) & $\begin{array}{c}-3.367 * * \\
(1.379)\end{array}$ & $\begin{array}{c}-0.046^{* *} \\
(p=0.031)\end{array}$ & $\begin{array}{c}-0.048^{* *} \\
(0.022)\end{array}$ & $\begin{array}{c}-0.040^{*} \\
(0.022)\end{array}$ \\
\hline News Pressure & & & $\begin{array}{c}0.002^{*} \\
(0.001)\end{array}$ & $\begin{array}{l}-0.008^{* * *} \\
(0.003)\end{array}$ \\
\hline Divided Government & $\begin{array}{l}1.231^{* * *} \\
(0.292)\end{array}$ & $\begin{array}{c}0.016 \\
(p=0.443)\end{array}$ & $\begin{array}{c}0.015 \\
(0.011)\end{array}$ & $\begin{array}{c}0.018 \\
(0.011)\end{array}$ \\
\hline War & $\begin{array}{c}0.910 \\
(0.732)\end{array}$ & $\begin{array}{c}0.004 \\
(p=0.803)\end{array}$ & $\begin{array}{c}0.000 \\
(0.009)\end{array}$ & $\begin{array}{c}0.018^{*} \\
(0.010)\end{array}$ \\
\hline Years after 1976 & $\begin{array}{c}-0.107 \\
(0.931)\end{array}$ & $\begin{array}{l}-0.002 \\
(p=0.955)\end{array}$ & $\begin{array}{r}-0.002 \\
(0.011)\end{array}$ & $\begin{array}{c}-0.003 \\
(0.012)\end{array}$ \\
\hline Years in Office & $\begin{array}{l}-3.682 * * * \\
(0.602)\end{array}$ & $\begin{array}{l}-0.032 * * \\
(p=0.031)\end{array}$ & $\begin{array}{r}-0.032 * \\
(0.017)\end{array}$ & $\begin{array}{r}-0.030^{*} \\
(0.017)\end{array}$ \\
\hline Years in Office ${ }^{2}$ & $\begin{array}{l}1.391 * * * \\
(0.133)\end{array}$ & $\begin{array}{c}0.012 * * \\
(p=0.029)\end{array}$ & $\begin{array}{l}0.012 * * \\
(0.005)\end{array}$ & $\begin{array}{l}0.012^{* *} \\
(0.005)\end{array}$ \\
\hline Years in Office $/ 10$ & $\begin{array}{l}-1.351^{* * * *} \\
(0.166)\end{array}$ & $\begin{array}{l}-0.012 * * \\
(p=0.031)\end{array}$ & $\begin{array}{l}-0.012^{* * * *} \\
(0.004)\end{array}$ & $\begin{array}{l}-0.011^{* * *} \\
(0.004)\end{array}$ \\
\hline Years Between Scandals & $\begin{array}{l}4.180^{* *} \\
(2.046)\end{array}$ & $\begin{array}{c}0.067 \\
(p=0.221)\end{array}$ & $\begin{array}{c}0.072 * \\
(0.041)\end{array}$ & $\begin{array}{c}0.051 \\
(0.040)\end{array}$ \\
\hline Years Between Scandals ${ }^{2}$ & $\begin{array}{c}-3.341 \\
(2.159)\end{array}$ & $\begin{array}{l}-0.065 \\
(p=0.223)\end{array}$ & $\begin{array}{c}-0.071 \\
(0.051)\end{array}$ & $\begin{array}{c}-0.048 \\
(0.050)\end{array}$ \\
\hline Years Between Scandals ${ }^{3} / 10$ & $\begin{array}{c}8.956 \\
(5.712)\end{array}$ & $\begin{array}{c}0.204 \\
(p=0.221)\end{array}$ & $\begin{array}{c}0.220 \\
(0.162)\end{array}$ & $\begin{array}{c}0.155 \\
(0.161)\end{array}$ \\
\hline House Days in Session & $\begin{array}{c}0.201 \\
(0.489)\end{array}$ & $\begin{array}{c}0.001 \\
(p=0.847)\end{array}$ & $\begin{array}{c}0.002 \\
(0.010)\end{array}$ & $\begin{array}{c}0.001 \\
(0.010)\end{array}$ \\
\hline Hurricane Peak & & & $\begin{array}{c}-0.002 \\
(0.007)\end{array}$ & $\begin{array}{c}0.003 \\
(0.008)\end{array}$ \\
\hline Presidential Fixed Effects & Yes & Yes & Yes & Yes \\
\hline Standard errors & $\begin{array}{l}\text { Clustered } \\
\text { (pres.) }\end{array}$ & $\begin{array}{l}\text { Clustered } \\
\text { (wild bootstrap) }\end{array}$ & $\begin{array}{c}\mathrm{HAC} \\
(\mathrm{bw}=4)\end{array}$ & $\begin{array}{c}\text { HAC } \\
(\mathrm{bw}=4)\end{array}$ \\
\hline Instrument for news pressure & & & & $\begin{array}{l}\text { Exogenous } \\
\text { news events }\end{array}$ \\
\hline $\begin{array}{l}\text { First-stage F } \\
\mathrm{N}\end{array}$ & 1670 & 1670 & 1670 & $\begin{array}{c}14.76 \\
1670\end{array}$ \\
\hline
\end{tabular}

Note: conditional logit results include standard errors clustered by president. The OLS results in the second column include $p$-values clustered by president computed using the wild bootstrap (Cameron, Gelbach and Miller 2008). I conduct 1,000 bootstrap replications, following their recommendation to impose the null hypothesis. The third and fourth columns present results with standard errors that are robust to arbitrary heteroscedasticity and autocorrelation (HAC) with a bandwidth of four weeks. IV regression results estimated using two-stage least squares. Constant omitted for the OLS model in the second column (not estimated for models in first, third and fourth columns due to conditional logit/IV fixed effects). ${ }^{*} p<0.10 ; * * p<0.05 ; * * * p<0.01$.

errors clustered by president. With only five presidents in the data, however, clustered standard errors may be too optimistic. ${ }^{97}$ To account for this issue, I also perform a robustness check in which I estimate a linear probability model with clustered standard errors computed using the wild bootstrap procedure, which performs adequately with as

97 Cameron, Gelbach, and Miller 2008. The opposition approval coefficient in the conditional logit model remains statistically significant with robust standard errors that are not clustered by president, however (available upon request). 


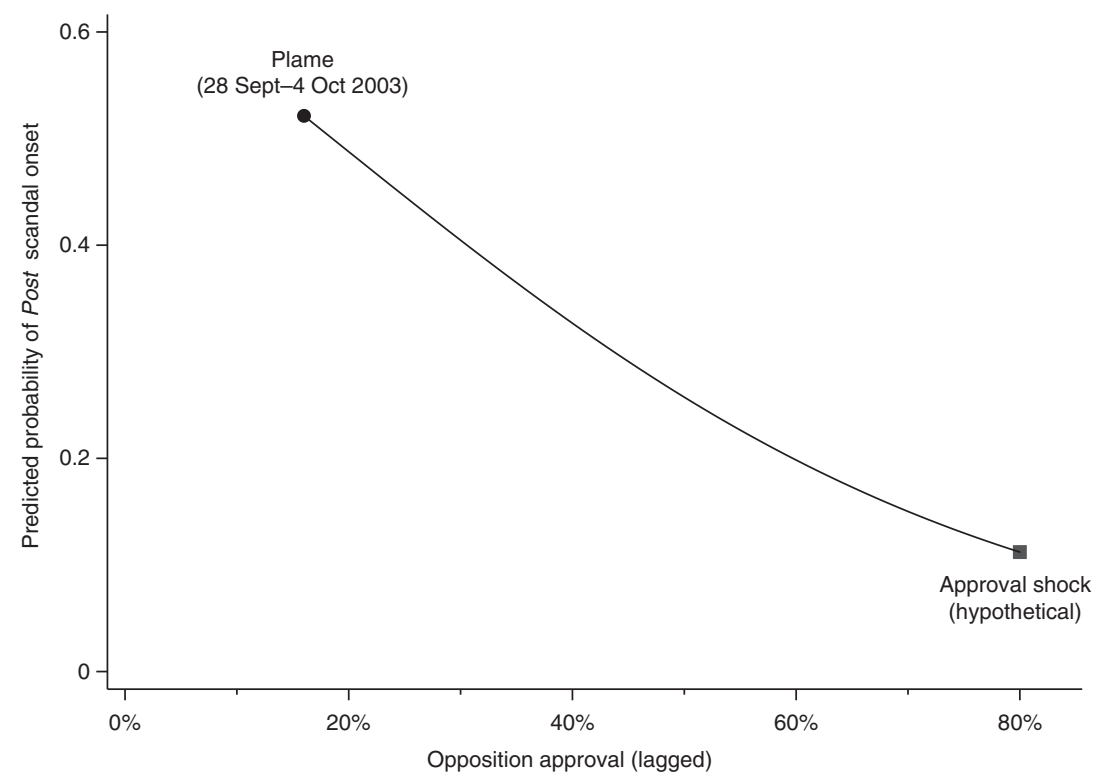

Fig. 1. Predicted effect of opposition approval surge: Valerie Plame

Note: predicted probabilities from the conditional logit model in Table 1 of the effect of a shock to lagged opposition approval with other variables held at their actual values for 6-11 October 2003. The presidential fixed effect is assumed to be zero, an assumption that is necessary to estimate out-of-sample predicted probabilities from a conditional logit model with more than one positive outcome per unit.

few as five clusters. ${ }^{98}$ The results of this robustness check, which also include presidential fixed effects, are presented in the second column of Table 1.

As Hypothesis 1 predicts, the lagged opposition approval term is negative and statistically significant in each of these models, suggesting that increased support for the president among opposition party identifiers decreases the subsequent likelihood of scandal. ${ }^{99}$ To illustrate the magnitude of the estimated relationship (which is difficult to assess when comparing conditional logit and OLS models), I estimate the predicted effects of opposition approval on the likelihood of scandal onset in a realistic counterfactual scenario. On 30 September 2003, the Justice Department announced an investigation into the leak of CIA operative Valerie Plame's name. President Bush's approval rating among Democrats was 16 per cent that month. Not surprisingly, the controversy quickly became a scandal and was recognized as such in the Post during the week of 6-11 October. I consider a counterfactual scenario in which a new crisis returned Democratic approval of Bush to its post-9/11 peak of 80 per cent in September. Setting aside the specifics of the Plame case, what would be the effects of such a boost in lagged opposition approval on the likelihood of scandal? The results of simulations using the conditional logit model from Table 1 are presented in Figure 1. Under this scenario, the predicted probability of scandal is dramatically reduced from 52 per cent in the Plame scenario to 11 per cent in the counterfactual - an almost fivefold decrease.

98 Cameron, Gelbach, and Miller 2008.

99 By contrast, lagged overall approval is not consistently significant, nor is lagged approval among independents or identifiers of the president's party (results available upon request). 
The negative relationship between media scandal onset and lagged presidential approval among opposition party identifiers withstands an extensive series of robustness tests (all results available upon request). For instance, the results remain statistically significant if the opposition approval measure is lagged by two calendar months instead of one. The results in the first two columns are also robust to the inclusion of various control variables, including the independent counsel statute, an election year indicator, years since 1976 squared (to account for a potential non-linear time trend), the percentage of households with cable television or internet access, the number of cable news subscribers or the distance between the party medians in Common Space DWNOMINATE. ${ }^{100}$ Another potential concern is that opposition approval is measured at the monthly rather than weekly level. However, the effect of lagged opposition approval remains negative and statistically significant if the model is instead estimated at the monthly level (results available upon request). An additional potential concern is that the baseline hazard may vary depending on the previous number of scandals. I find that the results are unchanged when I control for the number of past scandals. ${ }^{101}$ Finally, while one might be concerned about the effects of scandal on subsequent opposition approval, the data provide little evidence of endogeneity. ${ }^{102}$

The models in the third and fourth columns test Hypothesis 2, which predicts that increased news pressure will decrease the likelihood of a new media scandal. Due to the limitations of instrumental variables models for binary outcome measures discussed above, I first present a fixed effects OLS model with the endogenous news pressure variable in the third column before reporting a linear IV model with fixed effects, which instruments for news pressure using an indicator for exogenous news events, in the fourth column (both are estimated with standard errors that are robust to arbitrary heteroscedasticity and autocorrelation). The IV model performs well, passing numerous weak instrument diagnostics (results available upon request) including the first-stage $F$ threshold of 10 recommended by Staiger and Stock. ${ }^{103}$ Moreover, the OLS and IV results are quite different, allowing us to reject the null of exogeneity $(p<0.01){ }^{104}$ Specifically, while the OLS estimate of the effect of news pressure on scandal onset is positive and significant $(p<0.10)$, the estimated effect in the IV model is negative and significant $(p<0.05)$, as predicted by Hypothesis 2 . In substantive terms, news pressure reduces the likelihood of a new scandal once we account for the endogeneity between news pressure and scandal onset. These results are robust to instrumenting for news pressure in the previous week using a lagged exogenous news event indicator or including the exogenous

\footnotetext{
100 Poole and Rosenthal 1997, 2007.

101 Beck, Katz, and Tucker 1998, 1272. Because I treat George H.W. Bush's administration as a continuation of Reagan's (he suffered three scandals based on actions taken by the Reagan administration during his first year in office), I do not reset the event counter in 1989.

${ }^{102}$ When I regress opposition approval on its lagged value, the years in office polynomials and presidential fixed effects, I cannot reject the null hypothesis that lagged scandal onset has no effect on opposition approval for scandal lags of one, two, three or four weeks (standard errors clustered by president; results available upon request). While previous studies of the effect of scandal on approval have reached conflicting conclusions, the most comprehensive study estimates a model of approval using each event in their data as a separate variable (Newman and Forcehimes 2010). Only two - Billy Carter and Iran-Contra - are negative and significant.

${ }^{103}$ Staiger and Stock 1997. The first-stage results for the IV models in Tables 1 and 2 are provided in Online Appendix E.

${ }_{104}$ Though this test cannot prove that an instrument is truly exogenous, it allows us to test for equality of the estimated coefficients between models.
} 


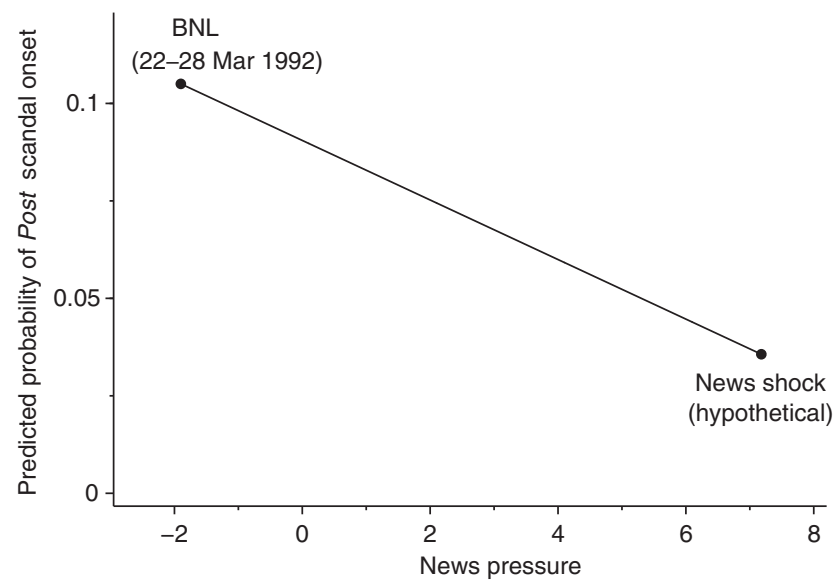

Fig. 2. Predicted effect of news shock on scandal onset: Banca Nazionale del Lavoro Note: predicted values from the instrumental variables linear probability model in Table 1 of the effect of a shock to news pressure with other variables held at their actual values for 22-28 March 1992.

news events measure directly in a reduced form model, which directly measures the effect of these events on the probability of scandal (both results available upon request).

To illustrate the substantive importance of this effect, I again provide a simulation of an unexpected shock to the treatment variable of interest. In this case, I consider a counterfactual scenario in the week in which the controversy over the Reagan and Bush administrations' handling of government-subsidized loans to Iraq by the Atlanta branch of Banca Nazionale del Lavoro was first recognized as a scandal on the front page of the Post (22-28 March 1992). It was a slow news week with news pressure at approximately the 10 th percentile of the distribution. What would happen to the predicted probability of scandal in that week if a breaking news event occurred? Specifically, I consider a scenario in which an unexpected event increased news pressure to the value observed after Princess Diana's death in 1997 ( 7.2 minutes above the yearly mean for lead evening news segments). Under this scenario, which is plotted in Figure 2, the predicted probability of scandal onset with other variables at their observed values declines by 66 per cent, dropping from 0.105 in the week in question to a counterfactual value of 0.036 .

In addition, the polynomials for time in office and time since last scandal, which are included to account for potential duration dependence or other temporal patterns in the data, have substantively and statistically significant effects. Likelihood ratio tests of nested models reject the null hypothesis that both the years in office and years between scandal polynomials are jointly zero ( $p<0.01$ in both cases), suggesting that both sets of terms should be included. To illustrate these effects, I follow the recommendation of Carter and Signorino and plot the estimated probabilities of scandal over time for a hypothetical president with representative covariate values in Figure $3 .^{105}$ Figure 3(a) plots the risk of scandal during a president's time in office. The Post data show an initially high risk of scandal as presidents try to find their footing and get their initial nominees confirmed, followed by a decline in scandal risk through their second year. The likelihood 
(a)

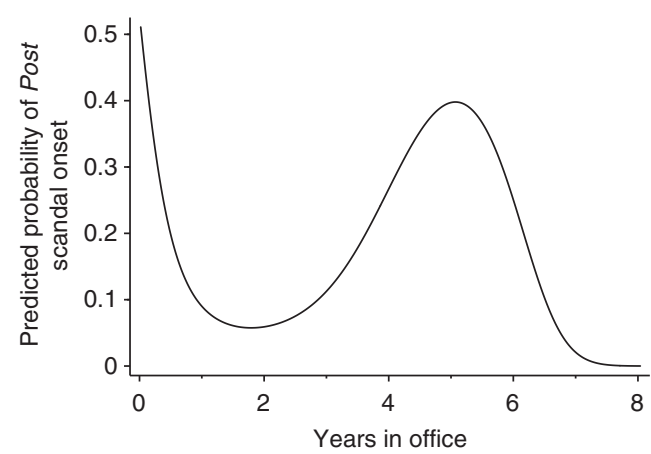

(b)

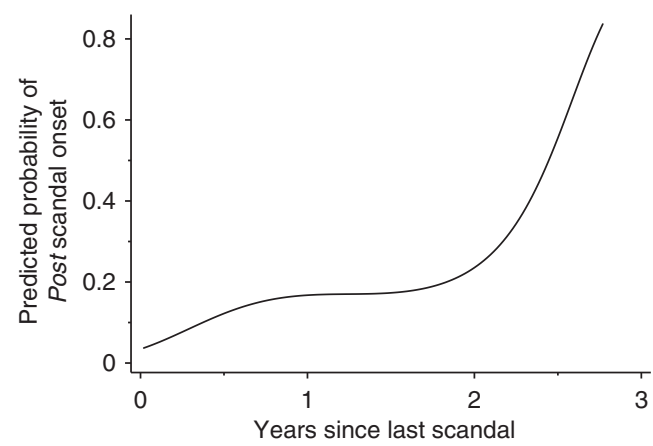

Fig. 3. Estimated duration dependence

Note: predicted probabilities from the conditional logit model in Table 1 with the presidential fixed effect set to zero. Continuous variables were set to their means; binary indicators and measures of elapsed time were set to their medians (polynomials were set accordingly).

of a scandal then increases again to a peak around their fifth year in office (for those who are re-elected) before declining by the end of their second term. By contrast, the results in Figure 3(b) show that the probability of scandal grows slowly as time since the last scandal increases for approximately two years before rising dramatically near the maximum observed value of almost three years.

Other covariates of interest show surprisingly weak patterns of support, particularly in the linear probability models. For instance, divided government has a positive and significant effect in the conditional logit model but not the OLS model. These inconsistent findings suggest that the association between divided government and scandal (as opposed to precursors such as investigations and allegations) may have been overstated in previous research. Similarly, the indicator for foreign wars, the time trend (which is highly correlated with legislative polarization and cable news penetration) and House days in session all fail to consistently achieve statistical significance. The fixed effects do not have statistically significant effects in the OLS and IV models - and are not estimated in the conditional logit model - so they are omitted from Table 1 for space reasons (but are available upon request).

Finally, the results supporting Hypotheses 1 and 2 in Table 1 are robust to using an alternate measure of scandal onset. In particular, one might be concerned about focusing on the recognition of a scandal in news coverage as the measure of onset. Online Appendix $\mathrm{F}$ therefore presents results for an alternative media scandal onset measure based on scandal-like events listed in chronologies that were widely covered on the front page of the New York Times. While the measure necessarily differs somewhat from the one based on the Post, due to its focus on the occurrence of discrete events rather than recognized scandals, the results for opposition approval and news pressure are completely consistent with those in Table 1 (that is, both coefficients are negative and statistically significant), despite using a different media source and coding procedure.

\section{Scandal Intensity}

The previous analysis considers scandal as a binary state. This approach does not allow for distinctions between major or minor scandals, nor does it allow for flurries of scandals 
developing within a given time period. Thus, building on the approach developed above, I use the volume of scandal news coverage as a proxy for the magnitude or intensity of media scandal - specifically, the total number of front-page Post stories that describe a controversy involving the president or executive branch as a scandal by week. ${ }^{106}$

As before, I estimate the effect of news pressure on media scandal using exogenous news events as an instrument. In this case, however, the dependent variable is scandal intensity, an overdispersed count variable with significant autocorrelation. ${ }^{107}$ Given the limitations of current IV event count models (which cannot simultaneously account for autocorrelation and overdispersion) and concerns about the robustness of generalized linear models (GLM) estimators to misspecification, ${ }^{108} \mathrm{I}$ instead use a linear IV model with standard errors that are robust to arbitrary heteroscedasticity and autocorrelation (HAC). The model specification is identical to Equations 1 and 3 above (I retain polynomials for time since the last scandal to account for dynamics in coverage between scandals).

The OLS and IV estimates for weekly front-page coverage in the Post are reported in Table 2. The estimated OLS coefficient for news pressure is positive and significant $(p<0.10)$. However, when endogeneity has been purged in the IV model, which again passes a variety of weak instrument diagnostics, the estimated effect of news pressure on scandal intensity is negative and statistically significant $(p<0.05)$. Consistent with Hypothesis 2, I find that increased news pressure reduces the intensity of media coverage of presidential and executive branch scandal.

Figure 4 illustrates the magnitude of the estimated effect using a counterfactual scenario for 18-24 March 2007, the peak of the US attorneys scandal. News pressure in that week was slightly above average for the year. In this scenario, I again leave all other variables at their observed values and estimate the effect of an exogenous news shock comparable to the one experienced from the Israel-Lebanon war during the week of 16-22 July 2006 (4.8 minutes above the yearly mean for the length of initial evening news segments). As news pressure increases from its observed value to the counterfactual level, the predicted number of front-page Washington Post scandal stories decreases from 0.67 to approximately zero (0.004). Given that Post scandal coverage is likely to be highly correlated with other elite media sources, this finding suggests that news pressure has a significant impact on presidential scandal coverage in the news media.

It is also instructive to consider the other coefficients from Table 2 and contrast them with the results in Table 1, which considered predictors of scandal onset rather than intensity. First, opposition approval is positively associated with scandal intensity, which reflects the confound between approval and re-election discussed above (presidents with higher approval are more likely to serve a second term, which is when the most significant scandals tend to occur). Secondly, the coefficients for divided government, war and years after 1976 are not consistently statistically significant, corroborating the inconsistent results in Table 1. Finally, the polynomials for years in office, which are highly significant,

\footnotetext{
${ }^{106}$ As with scandal onset, it is not possible to account for evidence of impropriety in analyzing this dependent variable. Even if reliable evidentiary data were available in longitudinal form (which they are not), including a measure of revealed evidence of misbehavior would induce post-treatment bias because the process that generates such revelations is affected by the contextual factors I analyze (King and Zeng 2006).

${ }^{107}$ The mean number of front-page scandal articles in the Post in a given week is 0.48 , with a standard deviation of 1.26. A regression of weekly Post scandal articles on their lagged value estimates that the coefficient on lagged articles is 0.60 (s.e. $=0.02$; results available upon request).

108 Angrist and Pischke 2009, 197-8.
} 
TA B L 2 News Pressure Models of Washington Post Scandal

Intensity 1977-2008 (weekly data)

\begin{tabular}{|c|c|c|}
\hline & OLS & IV reg. \\
\hline News Pressure & $0.03 *$ & $-0.14 * *$ \\
\hline Opposition Approval (lag) & $\begin{array}{l}0.99 * * * \\
(0.32)\end{array}$ & $\begin{array}{l}1.13^{* * *} \\
(0.37)\end{array}$ \\
\hline Divided Government & $\begin{array}{l}-0.18^{* *} \\
(0.09)\end{array}$ & $\begin{array}{c}-0.13 \\
(0.10)\end{array}$ \\
\hline War & $\begin{array}{l}-0.51 * * * \\
(0.09)\end{array}$ & $\begin{array}{r}-0.19 \\
(0.16)\end{array}$ \\
\hline Years after 1976 & $\begin{array}{c}0.10 \\
(0.16)\end{array}$ & $\begin{array}{c}0.08 \\
(0.17)\end{array}$ \\
\hline Years in Office & $\begin{array}{l}-0.76^{* * * *} \\
(0.26)\end{array}$ & $\begin{array}{l}-0.73^{* * *} \\
(0.26)\end{array}$ \\
\hline Years in Office ${ }^{2}$ & $\begin{array}{l}0.29 * * * \\
(0.08)\end{array}$ & $\begin{array}{l}0.29 * * * \\
(0.08)\end{array}$ \\
\hline Years in Office $3 / 10$ & $\begin{array}{l}-0.25^{* * *} \\
(0.07)\end{array}$ & $\begin{array}{l}-0.25^{* * *} \\
(0.07)\end{array}$ \\
\hline Years Between Scandals & $\begin{array}{c}0.17 \\
(0.58)\end{array}$ & $\begin{array}{c}(0.17 \\
-0.17 \\
(0.58)\end{array}$ \\
\hline Years Between Scandals ${ }^{2}$ & $\begin{array}{c}-0.24 \\
(0.51)\end{array}$ & $\begin{array}{c}0.14 \\
(0.51)\end{array}$ \\
\hline Years Between Scandals ${ }^{3} / 10$ & $\begin{array}{c}0.72 \\
(1.26)\end{array}$ & $\begin{array}{c}-0.38 \\
(1.27)\end{array}$ \\
\hline House Days in Session & $\begin{array}{c}0.05 \\
(0.13)\end{array}$ & $\begin{array}{c}0.04 \\
(0.13)\end{array}$ \\
\hline Hurricane Peak & $\begin{array}{c}0.10 \\
(0.12)\end{array}$ & $\begin{array}{c}0.20 \\
(0.14)\end{array}$ \\
\hline Presidential Fixed Effects & $\begin{array}{l}\text { Yes } \\
\text { HAC }\end{array}$ & Yes \\
\hline Instrument for news pressure & & Exogenous news events \\
\hline $\begin{array}{l}\text { First-stage } \mathrm{F} \\
\mathrm{N}\end{array}$ & 1670 & $\begin{array}{c}14.76 \\
1670\end{array}$ \\
\hline
\end{tabular}

Note: all results include standard errors that are robust to arbitrary heteroscedasticity and autocorrelation (HAC) with a bandwidth of four weeks. IV regression results estimated using two-stage least squares. $* p<0.10 ; * * p<0.05 ; * * * p<0.01$

produce similar dynamics to Figure 3(a) - an initial decline in expected coverage followed by a peak and decline in the second term (available upon request). ${ }^{109}$

\section{CONCLUSION}

Contrary to the prevailing interpretation of scandals as resulting from evidence of misconduct, I show that the occurrence of presidential media scandals is also significantly influenced by the political and news context. In particular, when the president is popular with opposition identifiers, scandals are unlikely, but the likelihood of scandal increases as the opposition base becomes more hostile to the administration. This article also presents the first systematic argument for the claim that media scandals are less likely to occur when other events are in the news. I develop a theory in which news pressure increases the opportunity costs of scandal coverage and test my predictions using

109 The presidential fixed effects were again not statistically significant (details available upon request). 


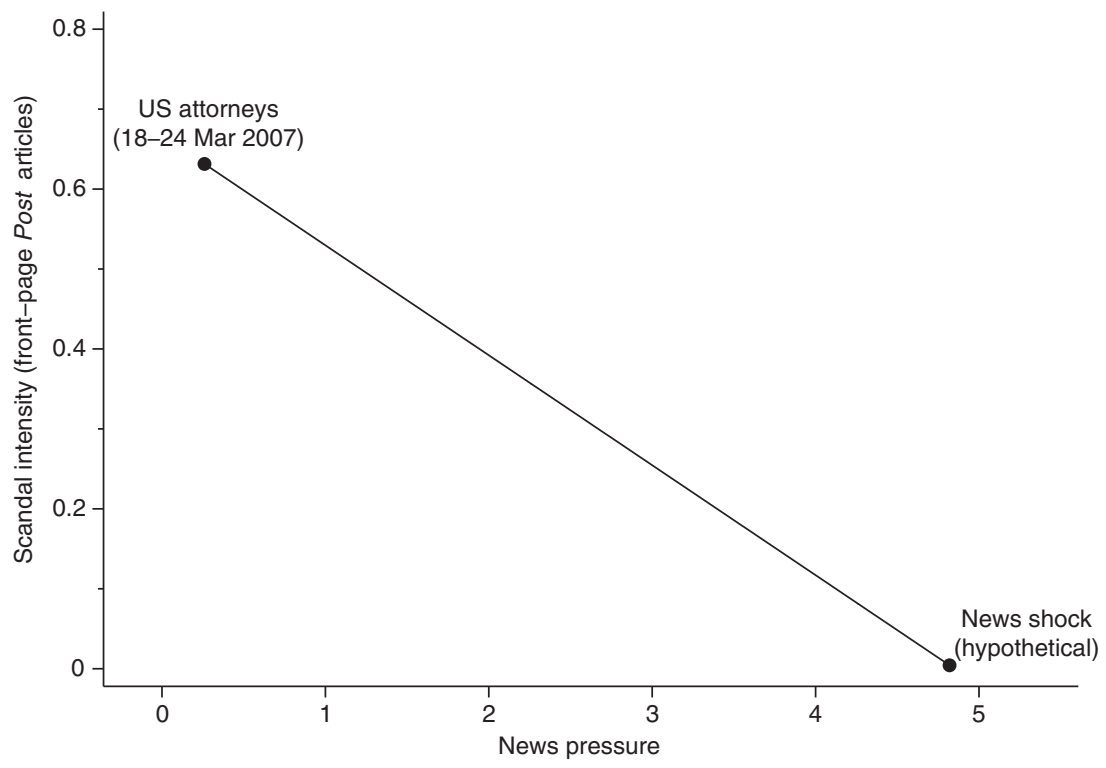

Fig. 4. Predicted effect of news shock on scandal coverage: US attorneys

Note: predicted values from the instrumental variables linear probability model in Table 2 of the effect of a shock to news pressure with other variables held at their actual values for 16-22 July 2006.

coverage of exogenous news events as an instrument for news pressure. My analyses indicate that congestion of the news agenda has a strongly negative influence on the onset of scandal and the extent of scandal coverage. Together, these findings help illuminate a phenomenon that plays a crucial role in contemporary American politics.

Future research should consider the extent to which these findings apply to other officeholders in the United States. The theory presented above seems to translate most directly to governors. As with presidents, state opposition party members have an incentive to promote scandal allegations against governors to damage his or her party brand name in the state, but demand for such allegations from opposition party identifiers will vary over time. Governors are also the subject of routinized news coverage from state media, which may pursue scandal coverage during slow news periods but focus on more compelling stories during periods of high news congestion in a similar fashion to the national press. ${ }^{110}$ By contrast, the demand for information about scandals involving individual members of Congress and state legislators (and the potential damage to the party brand that might result) is seemingly weaker than for governors and presidents, regardless of the political or media context. As a result, the scandals that lower-level officials face may be less influenced by contextual factors, though Gordon finds suggestive evidence to the contrary. ${ }^{111}$

The results presented above also have potentially important implications for the literature on scandal in comparative politics, including both presidential and parliamentary systems. For instance, the process by which events like scandals affect the stability of parliamentary

110 A similar argument might apply to Congressional leaders, though they are typically less well known at the national level than governors are in their states.

111 Gordon 2010. 
coalitions is the subject of an extensive literature. ${ }^{112}$ In particular, Lupia and Strøm argue that 'events such as wars, scandals, and economic shocks are not inherently critical' but instead 'become critical through their effects on parliamentary bargaining'. ${ }^{113}$ In this sense, then, the vulnerability of a coalition to scandal might depend on context in a similar manner to the theory I propose. ${ }^{114}$

Finally, my findings could be instructive to future research on the study of the presidency and the influence of presidential approval on political events. First, just as the chief executive's opportunities for leadership are shaped by the circumstances he faces in office, ${ }^{115}$ these results show how context affects the challenges that presidents face (including scandal). Secondly, my analysis suggests the potential value of disaggregating approval to focus on partisan identifiers, who may have a disproportionate influence on elite co-partisans.

Of course, this article has limitations that should be addressed in future scholarship. First, I rely on scandal coverage from Washington Post. Though the Post plays a key role in setting the news agenda for the national media's coverage of Washington politics, it would be desirable to consider a wider variety of outlets in future research. The present study is also limited by the small number of presidents in the contemporary era. My results are robust to presidential fixed effects, but it is difficult to reach strong conclusions about administration-level differences with so few presidents in the data. Future research should consider the predictors of scandal over a longer period (including extending the data to cover the Obama administration). Finally, scholars should examine how the president's response to an allegation may affect the likelihood of scandal ${ }^{116}-\mathrm{a}$ question I do not address here due to the small number of media scandals in my data, the different unit of analysis (time intervals rather than allegations), and the inferential challenges posed by post-treatment bias $^{117}$ and endogeneity in duration models. ${ }^{118}$

Nonetheless, these results have important implications for processes of democratic accountability. Normatively, we would like to hold elected officials accountable for misconduct based on evidence alone, but my results suggest that the likelihood of successful accusations of wrongdoing against presidents and their administrations is deeply shaped by the political and news context. Such an effect can have perverse consequences. When the environment is relatively unfavorable for scandal, it may weaken the incentives for ethical behavior by the president and his or her administration. By contrast, scandals will sometimes occur even when the evidence of misbehavior is weak if the environment is more favorable for scandal, which could potentially further undermine the credibility of ethical charges against the executive branch and increase cynicism about politics.

Finally, these findings raise questions about the broader influence of context on the creation and interpretation of political events in the media. Just as a flimsy allegation can create a scandal in certain circumstances, other triggering events may be more likely to be interpreted by journalists and other elites as gaffes or policy failures when the context is unfavorable for the president (and conversely for positive events). In this way, scandal

\footnotetext{
112 See, for example, Browne, Frendreis, and Gleiber 1986; King et al. 1990; Strøm et al. 1988.

113 Lupia and Strøm 1995, 651-52.

114 Similarly, Dewan and Myatt propose a model in which policy activism by cabinet ministers in parliamentary systems increases their vulnerability to scandal allegations from opposing interests (Dewan and Myatt 2007; see also Dewan and Myatt 2010)

115 Edwards 2009.

116 Basinger and Rottinghaus 2012.

117 King and Zeng 2006.

118 Boehmke, Morey, and Shannon 2006.
} 
may serve as a window into the highly contingent process by which political events are created and interpreted in a democratic society.

\section{REFERENCES}

Abramowitz, Alan I. 2008. Forecasting the 2008 Presidential Election With the Time-for-Change Model. PS: Political Science and Politics 41 (4):691-5.

Adut, Ari. 2005. A Theory of Scandal: Victorians, Homosexuality, and the Fall of Oscar Wilde. American Journal of Sociology 111 (1):213-48.

Agence France Presse. 2000. World's Worst Mass Suicides. Agence France Presse, 18 March.

Allen, Ira R. 1982. July: A Crazy Month in Washington. United Press International, 14 July.

Angrist, Joshua D., and Jörn-Steffens Pischke. 2009. Mostly Harmless Econometrics: An Empiricist's Companion. Princeton, NJ: Princeton University Press.

Apostolidis, Paul, and Juliet A. Williams. 2004. Introduction: Sex Scandals and Discourses of Power. In Public Affairs: Politics in the Age of Sex Scandals, edited by Paul Apostolidis and Juliet A. Williams. Durham, NC: Duke University Press.

Basinger, Scott J. 2013. Scandals and Congressional Elections in the Post-Watergate Era. Political Research Quarterly 66 (2):385-98.

Basinger, Scott, and Brandon Rottinghaus. 2012. Stonewalling and Suspicion During Presidential Scandals. Political Research Quarterly 65 (2):290-302.

Beck, Neal, Jonathan N. Katz, and Richard Tucker. 1998. Taking Time Seriously: TimeSeries-Cross-Section Analysis With a Binary Dependent Variable. American Journal of Political Science 42 (4):1260-88.

Bennett, W. Lance. 1990. Toward a Theory of Press-State Relations in the United States. Journal of Communication 40 (2):103-27.

- 2004. Gatekeeping and Press-Government Relations: A Multigated Model of News Construction. In Handbook of Political Communication Research, edited by Lynda Lee Kaid, 283-314. Mahwah, NJ: Lawrence Erlbaum Associates.

Bennett, W. Lance, Regina G. Lawrence, and Steven Livingston. 2006. None Dare Call it Torture: Indexing and the Limits of Press Independence in the Abu Ghraib Scandal. Journal of Communication 56 (3):467-85.

Best, Joel. 1993. But Seriously Folks: The Limitations of the Strict Constructionist Interpretation of Social Problems. In Reconsidering Social Constructionism: Debates in Social Problems Theory, edited by James A. Holstein and Gale Miller, 129-47. New Brunswick, NJ: Aldine.

Blais, André, Elisabeth Gidengil, Patrick Fournier, Neil Nevitte, Joanna Everitt, and Jiyoon Kim. 2010. Political Judgments, Perceptions of Facts, and Partisan Effects. Electoral Studies 29 (1):1-12.

Boehmke, Frederick J., Daniel S. Morey, and Megan Shannon. 2006. Selection Bias and Continuous-Time Duration Models: Consequences and a Proposed Solution. American Journal of Political Science 50 (1):192-207.

Bowler, Shaun, and Jeffrey A. Karp. 2004. Politicians, Scandals, and Trust in Government. Political Behavior 26 (3):271-87.

Box-Steffensmeier, Janet M., and Bradford S. Jones. 1997. Time is of the Essence: Event History Models in Political Science. American Journal of Political Science 41 (4):336-83.

Brady, David W., Hahrie Han, and Jeremy C. Pope. 2007. Primary Elections and Candidate Ideology: Out of Step with the Primary Electorate? Legislative Studies Quarterly 32 (1):79-105.

Brody, Richard A. 1991. Assessing the President: The Media, Elite Opinion, and Public Support. Stanford, CA: Stanford University Press.

Browne, Eric C., John P. Frendreis, and Dennis W. Gleiber. 1986. The Process of Cabinet Dissolution: An Exponential Model of Duration and Stability in Western Democracies. American Journal of Political Science 30 (3):628-50. 
Cameron, A. Colin, Jonah B. Gelbach, and Douglas L. Miller. 2008. Bootstrap-Based Improvements for Inference with Clustered Errors. The Review of Economics and Statistics 90 (3):414-27.

Cameron, A. Colin, and Pravin K. Trivedi. 2010. Microeconometrics Using Stata. College Station, TX: Stata Press.

Cameron, Charles M. 2002. Studying the Polarized Presidency. Presidential Studies Quarterly 32 (4):647-63.

Cannon, Carl M. 1993. Low Approval Rating in Polls Dogs Clinton. Buffalo News 14 April.

Carter, David B., and Curtis S. Signorino. 2010. Back to the Future: Modeling Time Dependence in Binary Data. Political Analysis 18:271-92.

CBSNews.com. 2009. Why We Mourn Intimate Strangers. 7 July.

Clayman, Steven E., John Heritage, Marc N. Elliott, and Laurie L. McDonald. 2007. When Does the Watchdog Bark? Conditions of Aggressive Questioning in Presidential News Conferences. American Sociological Review 72 (1):23-41.

Clinton, Joshua D. 2006. Representation in Congress: Constituents and Roll Calls in the 106th House. Journal of Politics 68 (2):397-409.

Cohen, Jeffrey E. 2008. The Presidency in the Era of 24-Hour News. Princeton, NJ: Princeton University Press.

—. 2010. Going Local: Presidential Leadership in the Post-Broadcast Age. New Yok: Cambridge University Press.

Cook, Charles E. 1991. Sununu After Flap: A Kinder, Gentler Chief of Staff? Roll Call 6 May.

Cook, Timothy E. 2005. Governing with the News: The News Media as a Political Institution, Second edition. Chicago, IL: University of Chicago Press.

Crouse, Timothy. 1973. The Boys on the Bus: Riding with the Campaign Press Corps. New York: Random House.

Dewan, Torun, and David P. Myatt. 2007. Scandal, Protection, and Recovery in the Cabinet. American Political Science Review 101 (1):63-77.

2010. The Declining Talent Pool of Government. American Journal of Political Science 54 (2):267-86.

Doherty, David, Conor M. Dowling, and Michael G. Miller. 2011. Are Financial or Moral Scandals Worse? It Depends. PS: Political Science \& Politics 44 (4):749-57.

Edwards, George C. 2009. The Strategic President: Persuasion and Opportunity in Presidential Leadership. Princeton, NJ: Princeton University Press.

Eisensee, Thomas, and David Strömberg. 2007. News Droughts, News Floods, and US Disaster Relief. The Quarterly Journal of Economics 122 (2):693-728.

Entman, Robert M. 1989. Democracy Without Citizens: Media and the Decay of American Politics. New York: Oxford University Press.

2004. Projections of Power: Framing News, Public Opinion, and US Foreign Policy. Chicago, IL: University of Chicago Press.

2012. Scandal and Silence: Media Responses to Presidential Misconduct. Malden, MA: Polity.

Fackler, Tim, and Tse-min Lin. 1995. Political Corruption and Presidential Elections, 1929-1992. Journal of Politics 57 (4):971-93.

Farnsworth, Stephen J. 2009. Spinner in Chief: How Presidents Sell Their Policies and Themselves. Boulder, CO: Paradigm Publishers.

Farnsworth, Stephen J., and S. Robert Lichter. 2004. Source Material: New Presidents and Network News: Covering the First Year in Office of Ronald Reagan, Bill Clinton, and George W. Bush. Presidential Studies Quarterly 34 (3):674-90.

- 2006. The Mediated Presidency: Television News and Presidential Governance. Lanham, MD: Rowman \& Littlefield.

Fine, Gary A. 1997. Scandal, Social Conditions, and the Creation of Public Attention: Fatty Arbuckle and the 'Problem of Hollywood'. Social Problems 44 (3):297-323.

Fischle, Mark. 2000. Mass Response to the Lewinsky Scandal: Motivated Reasoning or Bayesian Updating? Political Psychology 21 (1):135-59. 
Fogarty, Brian J. 2008. The Strategy of the Story: Media Monitoring Legislative Activity. Legislative Studies Quarterly 33 (3):445-69.

- 2013. Scandals, News Coverage, and the 2006 Congressional Elections. Political Communication 30 (3):419-33.

Fox, Gerald T. 2009. Partisan Divide on War and the Economy: Presidential Approval of G.W. Bush. Journal of Conflict Resolution 53 (6):905-33.

Funk, Carolyn L. 1996. The Impact of Scandal on Candidate Evaluations: An Experimental Test of the Role of Candidate Traits. Political Behavior 18 (1):1-24.

Gentzkow, Matthew, and Jesse M. Shapiro. 2010. What Drives Media Slant? Evidence from US Daily Newspapers. Econometrica 78 (1):35-71.

Ginsberg, Benjamin, and Martin Shefter. 2002. Politics by Other Means: Politicians, Prosecutors, and the Press from Watergate to Whitewater, 3rd edition. New York: W.W. Norton and Company.

Gordon, Sanford C. 2010. Assessing Partisan Bias in Federal Public Corruption Prosecutions. American Political Science Review 103 (4):534-54.

Green, Joshua. 2002. The Gate-less Community. Washington Monthly, July/August:8-14.

Groeling, Tim. 2010. When Politicians Attack! Party Cohesion in the Media. New York: Cambridge University Press.

Grynaviski, Jeffrey D. 2010. Partisan Bonds: Political Reputations and Legislative Accountability. New York: Cambridge University Press.

Hamilton, James T. 2004. All the News That's Fit to Sell: How the Market Transforms Information into News. Princeton, NJ: Princeton University Press.

Holcomb, Jesse, Amy Mitchell, and Tom Rosenstiel. 2011. The State of the News Media 2011. Pew Research Center's Project for Excellence in Journalism. Available from http://stateofthemedia.org/2011/cable-essay/data-page-2/, accessed 3 January 2013.

Insurance Information Institute. 2011a. Earthquakes. Available from http://www.iii.org/facts statistics/earthquakes.html, accessed 18 February 2011.

2011b. Hurricanes. Available from http://www.iii.org/facts_statistics/hurricanes.html, accessed 18 February 2011.

Jacobson, Gary C. 2003. Partisan Polarization in Presidential Support: The Electoral Connection. Congress \& the Presidency 30:1-36.

Jones, Jeffrey M. 2010. Obama’s Approval Most Polarized for First-Year President. Gallup.com, 25 January. Available from http://www.gallup.com/poll/125345/obama-approval-polarizedfirst-year-president.aspx, accessed 4 May 2013.

Kalb, Martin. 1998. The Rise of the 'New News': A Case Study of Two Root Causes of the Modern Scandal Coverage. Cambridge, MA: Shorenstein Center on the Press, Politics and Public Policy.

King, Gary, and Langche Zeng. 2006. The Dangers of Extreme Counterfactuals. Political Analysis $14(2): 131-59$.

King, Gary, James E. Alt, Nancy E. Burns, and Michael Laver. 1990. A Unified Model of Cabinet Dissolution in Parliamentary Democracies. American Journal of Political Science 34 (3):846-71.

Kriner, Douglas, and Liam Schwartz. 2008. Divided Government and Congressional Investigations. Legislative Studies Quarterly 33 (2):295-321.

Kunda, Ziva. 1990. The Case for Motivated Reasoning. Psychological Bulletin 108 (3):480-98.

Kurtz, Howard. 1991. Scandal. Washington Post Magazine, 22 September.

Layman, Geoffrey C., Thomas M. Carsey, John C. Green, Richard Herrera, and Rosalyn Cooperman. 2010. Activists and Conflict Extension in American Party Politics. American Political Science Review 104 (2):324-46.

Lebo, Matthew J., and Daniel Cassino. 2007. The Aggregated Consequences of Motivated Reasoning and the Dynamics of Partisan Presidential Approval. Political Psychology 28 (6):719-46.

Lupia, Arthur, and Kaare Strøm. 1995. Coalition Termination and the Strategic Timing of Parliamentary Elections. American Political Science Review 89 (3):648-65. 
Markovits, Andrei, and Mark Silverstein. 1988. Power and Process in Liberal Democracies. The Politics of Scandal, edited by Andrei Markovits and Mark Silverstein. New York: Holmes and Meier.

Mayhew, David R. 2005. Divided We Govern: Party Control, Lawmaking, and Investigations, 1946-2002, 2nd edition. New Haven, CT: Yale University Press.

Meinke, Scott R., and William D. Anderson. 2001. Influencing from Impaired Administrations: Presidents, White House Scandals, and Legislative Leadership. Legislative Studies Quarterly 26 (4):639-59.

Molotch, Harvey, and Marilyn Lester. 1974. News as Purposive Behavior: On the Strategic Use of Routine Events, Accidents, and Scandals. American Sociological Review 39 (1):101-12.

Newman, Brian, and Andrew Forcehimes. 2010. 'Rally Round the Flag' Events for Presidential Approval Research. Electoral Studies 29 (1):144-54.

Ostrom, Charles W., and Dennis M. Simon. 1985. Promise and Performance: A Dynamic Model of Presidential Popularity. American Political Science Review 79 (2):334-58.

Parker, David C. W., and Matthew Dull. 2009. Divided We Quarrel: The Politics of Congressional Investigations, 1947-2004. Legislative Studies Quarterly 34 (3):319-45.

- 2013. Rooting Out Waste, Fraud, and Abuse: The Politics of House Committee Investigations, 1947 to 2004. Political Research Quarterly 66 (3):630-44.

Peters, John G., and Susan Welch. 1980. The Effects of Charges of Corruption on Voting Behavior in Congressional Elections. American Political Science Review 74 (3):697-708.

Poole, Keith T., and Howard Rosenthal. 1997. Congress: A Political-Economic History of Roll Call Voting. New York: Oxford University Press.

2007. Ideology and Congress. New Brunswick, NJ: Transaction Publishers.

Prentice, R. L., B. J. Williams, and A. V. Peterson. 1981. On the Regression Analysis of Multivariate Failure Time Data. Biometrika 68 (2):373-9.

Puglisi, Riccardo, and James M. Snyder. 2011. Newspaper Coverage of Political Scandals. Journal of Politics 73 (3): 1-20.

Redlawsk, David P. 2002. Hot Cognition or Cool Consideration? Testing the Effects of Motivated Reasoning on Political Decision Making. Journal of Politics 64 (4):1021-44.

Robinson, Michael J. 2007. The News Interest Index, 1986-2007. Pew Research Center for the People and the Press, 15 August.

Rosenbaum, David E. 2003. First a Leak, Then a Predictable Pattern. New York Times, 3 October.

Sabato, Larry. 1991. Feeding Frenzy: How Attack Journalism has Transformed American Politics. New York: Free Press.

Shogan, Colleen J. 2006. The Contemporary Presidency: The Sixth Year Curse. Presidential Studies Quarterly 36 (1):89-101.

Smith, Craig A., and Kathy B. Smith. 1994. The White House Speaks: Presidential Leadership as Persuasion. Westport, CT: Praeger Publishers.

Smith, Patrick. 2009. Is Your Pilot Drunk? salon.com. Available from http://www.salon.com/ technology/ask_the_pilot/2009/11/12/askthepilot341, accessed 18 February 2011.

Snyder, James M., and Michael M. Ting. 2002. An Informational Rationale for Political Parties. American Journal of Political Science 46:90-110.

Staiger, Douglas, and James H. Stock. 1997. Instrumental Variables Regression with Weak Instruments. Econometrica 65 (3):557-86.

Stimson, James A. 2004. Tides of Consent: How Public Opinion Shapes American Politics. New York: Cambridge University Press.

Strøm, Kaare, Eric C. Browne, John P. Frendreis, and Dennis W. Glieber. 1988. Contending Models of Cabinet Stability. American Political Science Review 82 (3):923-41.

Szasz, Andrew. 1986. The Process and Significance of Political Scandals: A Comparison of Watergate and the 'Sewergate' Episode at the Environmental Protection Agency. Social Problems 33 (3):202-17.

Taber, Charles S., and Milton Lodge. 2006. Motivated Skepticism in the Evaluation of Political Beliefs. American Journal of Political Science 50 (3):755-69. 
Thompson, John. 2000. Political Scandal: Power and Visibility in the Media Age. Malden, MA: Polity.

Tuchman, Gaye. 1972. Objectivity as Strategic Ritual: An Examination of Newsmen's Notions of Objectivity. American Journal of Sociology 77 (4):660-79.

Violence Policy Center. 2007. Violence Policy Center Statement on Virginia Tech Shooting, Deadliest in US History. Press release, 16 April. Available from http://www.vpc.org/press/ 0704vatech.htm, accessed 7 February 2011.

Waisbord, Silvio R. 2004. Scandals, Media, and Citizenship in Contemporary Argentina. American Behavioral Scientist 47 (8):1072-98.

Welch, Susan, and John R. Hibbing. 1997. The Effects of Charges of Corruption on Voting Behavior in Congressional Elections, 1982-1990. Journal of Politics 59 (1):226-39.

Woolgar, Steve, and Dorothy Pawluch. 1985. Ontological Gerrymandering: The Anatomy of Social Problems Explanations. Social Problems 32 (3):214-27.

York, Byron. 2001. Clinton Has No Clothes: What 9/11 Revealed About the Ex-president. National Review 53 (24):34-8.

Zaller, John, and Dennis Chiu. 1996. Government's Little Helper: US Press Coverage of Foreign Policy Crises, 1945-1991. Political Communication 13 (4):385-405.

Zimmer, Troy A. 1979. The Impact of Watergate on the Public's Trust in People and Confidence in the Mass Media. Social Science Quarterly 58 (4):743-52.

APPENDIX A：LIST OF MEDIA SCANDALS

\begin{tabular}{|c|c|c|}
\hline Scandal & Administration & Onset date \\
\hline GSA corruption & Carter & 27 July 1978 \\
\hline Billy Carter & Carter & 10 September 1980 \\
\hline Hugel finances & Reagan & 24 July 1981 \\
\hline EPA document controversy & Reagan & 2 December 1983 \\
\hline Donovan charges & Reagan & 3 October 1984 \\
\hline DOD procurement & Reagan & 3 June 1985 \\
\hline Iran-Contra & Reagan & 27 November 1986 \\
\hline Wedtech contracts & Reagan & 10 July 1987 \\
\hline S\&L failures/bailout & G.H.W. Bush & 15 May 1989 \\
\hline HUD corruption & G.H.W. Bush & 8 July 1989 \\
\hline FDA generic drugs & G.H.W. Bush & 1 September 1989 \\
\hline Banca Nazionale del Lavoro & G.H.W. Bush & 22 March 1992 \\
\hline Tailhook controversy & G.H.W. Bush & 27 June 1992 \\
\hline Whitewater & Clinton & 1 July 1994 \\
\hline Travel Office firings & Clinton & 5 January 1996 \\
\hline Dick Morris & Clinton & 30 August 1996 \\
\hline Filegate & Clinton & 26 October 1996 \\
\hline Foreign contributions & Clinton & 21 December 1996 \\
\hline 1996 fundraising & Clinton & 13 February 1997 \\
\hline Military sexual harassment & Clinton & 31 May 1997 \\
\hline Links to Carey/Teamsters & Clinton & 6 October 1997 \\
\hline Lewinsky affair & Clinton & 24 January 1998 \\
\hline China spying/Los Alamos & Clinton & 14 March 1999 \\
\hline Valerie Plame & G.W. Bush & 5 October 2003 \\
\hline Abu Ghraib & G.W. Bush & 6 May 2004 \\
\hline Prisoner treatment & G.W. Bush & 7 January 2005 \\
\hline Safavian convicted & G.W. Bush & 21 June 2006 \\
\hline US attorneys & G.W. Bush & 21 March 2007 \\
\hline
\end{tabular}




\section{Coding Procedure}

- The Post was searched in Lexis-Nexis Academic for '[president name]' OR 'president' OR 'white house' in the fields for headline, lead paragraphs or terms.

- The search results were then narrowed to news articles that included the word 'scandal' in the A section (previously called 'First Section'). Featured news columnists who write in an opinionated voice (such as Mary McGrory or Dana Milbank) were excluded.

- If a specific controversy was referred to as a 'scandal' in the reporter's voice or the headline, the date and scandal were recorded.

- If more than one controversy was described as a scandal in the same article, then a separate entry was created for each scandal reference.

- References to 'alleged' scandals were omitted, as were vague descriptions of people or organizations as 'scandal ridden' or 'scandal plagued'.

- Controversies about actions taken by the executive branch under previous administrations were excluded (except for those of President George H.W. Bush, who was held responsible for events that took place when he was Ronald Reagan's vice president).

- Scandals that did not directly involve the executive branch (such as the collapse of Enron or bond trading scandals on Wall Street) were also omitted. However, controversies over past actions taken by individuals in the executive branch (such as Whitewater) were included if those controversies took place while the administration held office.

- Articles were coded as focusing on a given scandal if the article devoted at least one of the first three paragraphs to the controversy. ${ }^{19}$

\section{Dependent Variables}

- Scandal Onset: the calendar week in which a controversy was first described as a 'scandal' in the Post in a front-page article meeting the above criteria.

- Scandal Intensity: the total number of articles describing a controversy as a 'scandal' in the Post in a given calendar week.

119 The initial paragraphs of a news article describe the focus of a story or summarize its most important elements in the inverted pyramid structure typically used in American print journalism. 
APPENDIX B: EXOGENOUS NEWS EVENTS

\begin{tabular}{lll}
\hline \hline News event & Administration & Week coded \\
\hline Elvis Presley's death & Carter & 14-20 August 1977 \\
Jonestown suicides & Carter & 19-25 November 1978 \\
American Airlines Flight 191 crash & Carter & 27 May-2 June 1979 \\
John Lennon's murder & Carter & 7-13 December 1980 \\
Pan Am Flight 759 crash & Reagan & 11-17 July 1982 \\
McDonald's shootings (San Ysidro, CA) & Reagan & 15-21 July 1984 \\
Post office shootings (Edmund, OK) & Reagan & 17-23 August 1986 \\
Northwest Airlines Flight 255 crash & Reagan & 16-22 August 1987 \\
Hurricane Hugo & G.H.W. Bush & 17-23 September 1989 \\
Loma Prieta earthquake & G.H.W. Bush & 15-21 October 1989 \\
Luby's Cafeteria shootings (Killeen, TX) & G.H.W. Bush & 13-19 October 1991 \\
Hurricane Andrew & G.H.W. Bush & 23-29 August 1992 \\
Northridge earthquake & Clinton & 16-22 January 1994 \\
TWA Flight 800 crash & Clinton & 14-20 July 1996 \\
Heaven's Gate suicides & Clinton & 23-29 March 1997 \\
Princess Diana dies & Clinton & 31 August-6 September 1997 \\
Columbine shootings & Clinton & 18-24 April 1999 \\
John F. Kennedy, Jr. crash & Clinton & 18-24 July 1999 \\
American Airlines Flight 587 crash & G.W. Bush & 11-17 November 2001 \\
Hurricane Charley & G.W. Bush & 8-14 August 2004 \\
Hurricane Frances & G.W. Bush & 5-11 September 2004 \\
Hurricane Ivan & G.W. Bush & 12-18 September 2004 \\
Hurricane Jeanne & G.W. Bush & 26 September -2 October 2004 \\
Hurricane Rita & G.W. Bush & 18-24 September 2005 \\
Hurricane Charley & G.W. Bush & 23-29 October 2005 \\
Virginia Tech shootings & G.W. Bush & 15-21 April 2007 \\
Hurricane Ike & G.W. Bush & 7-13 September 2008 \\
\hline \hline
\end{tabular}

This list includes the five worst mass shootings as measured by number of deaths, ${ }^{120}$ the nine worst hurricanes in US history by property damage, ${ }^{121}$ the four most iconic celebrity deaths of unnatural causes during the 1977-2008 period, ${ }^{22}$ the two worst earthquakes by property damage, ${ }^{123}$ the two worst mass suicides ${ }^{124}$ and the five worst plane crashes in the United States by number of fatalities. ${ }^{125}$

120 Violence Policy Center 2007.

${ }^{121}$ Insurance Information Institute 2011b. I use the top ten worst hurricanes but exclude Hurricane Katrina, which damaged George W. Bush politically.

122 CBSNews.com 2009.

${ }^{123}$ Insurance Information Institute 2011a. The next most severe earthquake created vastly less damage.

124 Agence France Presse 2000. Only three of the ten worst mass suicides involved Americans. I include the Jonestown massacre even though it took place outside the geographic U.S. because the victims were American. However, I exclude the 1993 Branch Davidian fire because the Clinton administration was accused of misconduct after the incident.

${ }^{125}$ Smith 2009. 